INTER NATIONAL MONETARY FUND

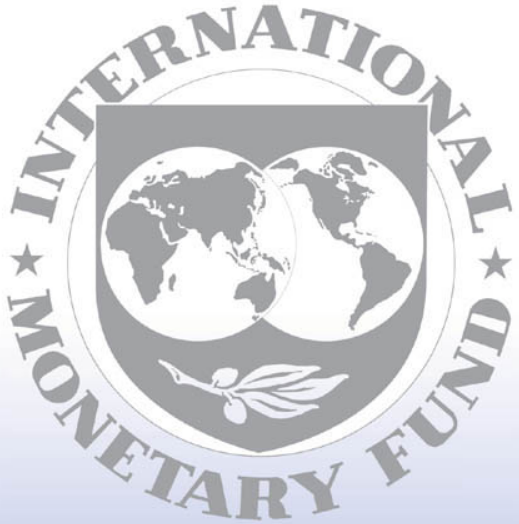

Staff

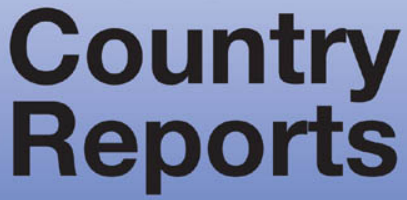




\section{Mexico: Financial Sector Assessment Program Update- Detailed Assessment of Compliance with the Basel Core Principles for Effective Banking Supervision and Transparency of Banking Supervision}

This Detailed Assessment of Compliance with the Basel Core Principles for Effective Banking Supervision and Transparency of Banking Supervision for Mexico was prepared by a staff team of the International Monetary Fund and the World Bank as background documentation to the Financial Sector Assessment Program Update with the member country. It is based on the information available at the time it was completed in November 2006. The views expressed in this document are those of the staff team and do not necessarily reflect the views of the government of Mexico or the Executive Board of the IMF.

The policy of publication of staff reports and other documents by the IMF allows for the deletion of market-sensitive information.

To assist the IMF in evaluating the publication policy, reader comments are invited and may be sent by e-mail to publicationpolicy@imf.org.

Copies of this report are available to the public from

International Monetary Fund • Publication Services

700 19th Street, N.W. • Washington, D.C. 20431

Telephone: (202) 6237430 • Telefax: (202) 6237201

E-mail: publications@imf.org • Internet: http://www.imf.org

Price: $\$ 18.00$ a copy

\section{International Monetary Fund Washington, D.C.}


This page intentionally left blank 


\section{Financial Sector Assessment Program Update MEXICO}

\section{DETAILED ASSESSMENT OF COMPlianCE WITH THE BASEl CORE PRINCIPLES FOR EFFECTIVE BANKING SUPERVISION AND TRANSPARENCY OF BANKING SUPERVISION}

NOVEMBER 2006

THE WORLD BANK

FINANCIAL AND PRIVATE SECTOR DEVELOPMENT VICE PRESIDENCY

LATIN AMERICA \& CARIBBEAN VICE PRESIDENCY
INTERNATIONAL MONETARY FUND MONETARY AND CAPITAL MARKETS DEPARTMENT 


\section{Contents}

Glossary

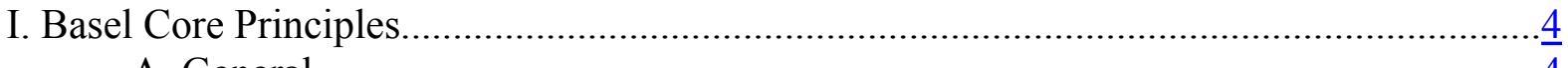

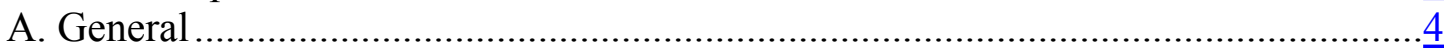

B. Institutional and Macroprudential Setting, Market Structure-Overview ................. 4

C. General Preconditions for Effective Banking Supervision .................................. $\frac{5}{6}$

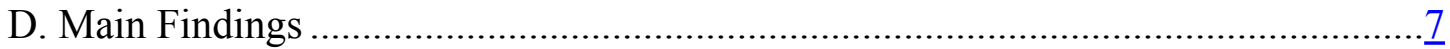

Tables

1. Detailed Assessment of Compliance of the Basel Core Principles for Effective Banking

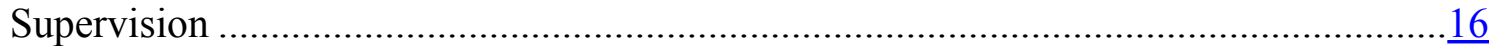

2. Summary of Compliance with Basel Core Principles..................................................... $\underline{38}$

3. Recommended Action Plan to Improve Compliance of the Basel Core Principles.............. $\underline{39}$ 


\section{GLOSSARY}

\begin{tabular}{|ll|}
\hline AFOREs & Privately managed pension funds \\
\hline AMIB & Association of Securities Intermediaries \\
\hline Bolsa & Stock Exchange \\
\hline BOM & Bank of Mexico \\
\hline CNBV & National Banking and Securities Commission \\
\hline CNSF & National Insurance and Sureties Commission \\
\hline CONSAR & Pension Fund Commission \\
\hline FSAP & Financial System Assessment Program \\
\hline GDP & Gross Domestic Product \\
\hline IMF & International Monetary Fund \\
\hline IPAB & Institute for the Protection of Banking Savings \\
\hline IT & Information Technology \\
\hline LIC & Law of Credit Institutions \\
\hline LMV & Securities Markets Law \\
\hline LSI & Mutual Funds Law \\
\hline MexDer & Mexico's derivatives market \\
\hline MOUs & Memoranda of Understanding \\
\hline P\&A & purchase and assumptions \\
\hline PCA & Prompt corrective action \\
\hline SHCP & Secretariat of Finance and Public Credit \\
\hline SHF & Federal Mortgage Society, a state development bank \\
\hline Sofoles & Nondeposit-taking credit institutions \\
\hline SROs & Self-regulatory organizations \\
\hline VAR & Value at Risk \\
\hline
\end{tabular}




\section{Basel Core Principles}

\section{A. General}

1. This report assesses the compliance by the National Banking and Securities Commission (CNBV), as the main authority responsible for banking supervision in Mexico, with the Basel Core Principles for Effective Banking Supervision as of February 2006. This assessment was conducted as part of the joint World Bank/IMF FSAP Update mission, which visited Mexico City on February 22-March 7, 2006. The assessor was Mr. Rudolph Zepeda, Jr. (Directing Bank Examiner, Federal Reserve Bank of Atlanta).

2. The assessment is based on an examination of key documents and discussions with senior officials of the CNBV, the Bank of Mexico (BOM), and the Secretariat of Finance and Public Credit (SHCP). In addition, discussions were held with bankers and other financial sector participants. Through these interviews, and the review of documents, it has been possible to form an opinion on the supervisory tools available to the Mexican authorities, to identify shortcomings, and to recommend changes where necessary. The assessor enjoyed the full cooperation of his counterparts and received all the necessary information.

\section{B. Institutional and Macroprudential Setting, Market Structure-Overview}

3. Economic reforms over the last decade have strengthened economic fundamentals and contributed to a more stable economy, but growth has not risen to a sustainable higher path. Fiscal consolidation reduced the gross public debt to GDP ratio to below 50 percent, providing the foundations for a monetary policy able to bring inflation down to less than 4 percent, in the context of a floating exchange rate. These improvements have contributed to Mexico's achievement of investment-grade rating, uninterrupted access to capital at low cost, and resilience to shocks, such as the Russian crisis. However, Mexico has not achieved strong and sustained rates of economic growth, partly due to an incomplete reform agenda. After a recession in 2002-2003, real GDP rose to 4.4 percent in 2004, declined to 3 percent in 2005, and the consensus forecast sees growth close to 4 percent for 2006.

4. The main risk factors for the Mexican financial system are linked to global and domestic developments. A slowdown of the U.S. industrial production would have an adverse effect on domestic economic activity and, in turn, on the demand for credit and the quality of loan portfolios. Also, the economy, and particularly the fiscal accounts, have become more reliant on oil and adverse developments in this sector (oil production and prices) could result in increasing borrowing requirements by the public sector with crowding-out effects. Although progress was made in extending the maturity and duration of government domestic debt, they remain relatively short and vulnerable to a tightening of global liquidity and sharp increases in interest rates which could lead to increased volatility in the financial system. Finally, notwithstanding significant progress in financial system 
reform, some gaps in regulation and supervision remain, particularly regarding consolidated supervision and the autonomy of the supervisory agencies (Comisiones).

5. The financial system is diverse - it includes commercial banks, insurance companies, pension funds, securities firms, investment banks, development banks, and nondeposit-taking credit institutions (Sofoles) — but with a dominant presence of large foreign-owned financial conglomerates. Commercial banks account for 49 percent of financial system assets. The banking sector exhibits a high degree of concentration (the three largest institutions account for close to 60 percent of the banking sector's assets) and a high degree of foreign ownership (representing close to 80 percent of all banking assets as of September 2005). Development banks, privately managed pension funds (AFOREs), and mutual funds account for 13, 13, and 11 percent, respectively, of financial system assets. Insurance, Sofoles, and other financial institutions are making important strides and account for the other 14 percent. Sofoles do not take deposits, and are licensed by the SHCP to grant credit to specific segments of the economy. The bulk of the financing of mortgage Sofoles comes from the Federal Mortgage Society (SHF), a development bank, although some institutions have started to tap the private market and, in the last two years, several of the large mortgage Sofoles have been acquired by private banks. Large, multinational financial groups that are involved in virtually all the salient lines of financial business (banking, insurance, asset and fund management, brokerage, and pension fund administration) dominate the Mexican financial landscape, with the exception of insurance.

\section{General Preconditions for Effective Banking Supervision}

6. Mexico has made significant strides in increasing transparency and market discipline and in strengthening the institutional framework for financial oversight. Overall transparency, including accounting and disclosure standards in the financial system, has vastly improved. This, together with the limitation of the previously unlimited guarantee on bank liabilities, has significantly boosted market discipline. At the same time, the regulatory and supervisory framework has registered remarkable improvements in quality and effectiveness, although some issues remain regarding the distribution of regulatory functions, coordination, and regulatory and supervisory gaps.

7. The financial system is overseen by multiple regulators. The SHCP sets regulatory policy for the financial system, particularly license granting and removal for banks, as well as capital requirements. The CNBV is the supervisor and regulator for banks, other credit institutions, and securities markets. The BOM has regulatory responsibilities, including money, foreign exchange, and derivatives markets; payment systems; and financial operations and product characteristics. The Pension Fund Commission (CONSAR) oversees AFOREs and the National Insurance and Sureties Commission (CNSF) oversees insurance companies. The institutional framework also includes the Mexican Association of Securities Intermediaries (AMIB), which administers qualification exams for employees of brokers, mutual funds, and banks engaged in the sale of securities, the Stock Exchange (Bolsa), and 
MexDer (Mexico's derivatives market). The Institute for the Protection of Banking Savings (IPAB), the bank resolution and deposit insurance agency, is also charged with disposing of the distressed assets inherited from the 1994 Tequila crisis. The professionalism of these agencies is well recognized in the markets.

8. The 2001 FSAP noted that the CNBV resorted on a regular basis to forbearance during the 1994-95 banking crisis and, as a consequence, its standing and credibility in the perception of market participants was undermined. Its autonomy needed to be strengthened as political interference in decision-making and politically imposed budgetary constraints were attendant problems that undermined its operational independence. There was a fragmentation of supervisory powers which weakened accountability and the enforcement of rules and regulations. A legal limitation was preventing foreign supervisors from gaining access to relevant information, but legislative amendments approved in April 2001 addressed this issue. Further actions were necessary to achieve consistency in the treatment of information, decision making, and enforcement within the CNBV. Greater contribution from the Boards of Directors and external auditors needed to be fostered and coupled with appropriate accountability. The legal reforms approved by Congress in April 2001 (including the minimum requirement of 25 percent of independent Board members in the banks' Boards of Directors) were expected to significantly correct existing deficiencies. The definition of capital in effect at the time did not reflect the actual bank's economic capitalization to cover losses.

9. Since the 2001 FSAP, legislation was passed mandating the critical systems for sound banking practices within the banking community. Reform legislation was passed on December 2, 2005, including improvements in the risk management system with a risk manager to control the financial institution's risks. This supplemented the mandated internal control systems introduced in late 2001. The mandated Basel I's capital standards and the introduction of the new Basel II's standards required significant changes in the way banks account for credit activities in their accounting. The revamping of the credit rating and provisioning regulations in August 2004 ensured that banks could apply internal credit rating methodologies for all types of loans (consumer, mortgage, and commercial); while also applying specific credit rating methodologies for loans to states and municipalities. It also made use of credit risk mitigation techniques on loans, guarantees, and collateral. It allowed the CNBV to have more accurate classifications of loans and provisioning for adequate loanloss reserves, and established a requirement of additional provisions for foreclosed assets. Credit ratings for municipalities were required for the granting of credit with substantial loan-loss reserves required for unrated municipalities. The new legislation also addresses credit diversification, underwriting, and accountability assigned to bank officers.

10. Regulations have been issued to ensure transparency in financial disclosure by financial institutions and a standardized format for regulatory reporting. The CNBV issued a regulatory accounting standard in accordance with international accounting standards for all banks to include all subsidiaries within a group supervised by the CNBV. Regulations aimed 
at enhancing the disclosure of information by banking institutions and financial groups were also issued by the CNBV. Regulations related to external auditors were issued in 1994 and 2000 and further strengthened in April 2005. The definition of "independence" of external auditors was updated and revised. Specific guidelines regarding requirements for independence of external auditors were established. They limit the contracting of additional services from the same firm such as bookkeeping or other services related to accounting records; services for the design and implementation of financial information systems; appraisal or valuation services; internal audit services; and some legal services.

11. Capital standards were strengthened in accordance with Basel I and preparations are underway for the implementation of the Basel II capital requirements. The SHCP introduced modifications in the capital adequacy regulation in accordance with the initial Basel Capital Accord, particularly concerning market risk and further reducing the participation of deferred assets in Tier 1 capital. However, it is worth mentioning that since 1997, the capital adequacy regulation considered a specific requirement for market risk that included the trading book as well as the banking book. The authorities are now preparing a new capital adequacy regulation to comply with Basel II. Also, the CNBV rates (in five categories) the capital levels (in relation to risk-weighted assets) of banks and provides this information on its website.

12. In November 2004 the CNBV established a framework with minimum capital triggers under which prompt corrective action (PCA) is undertaken allowing for the resolution of problem banks in concert with the IPAB. New legislation has also established an early warning system.

13. A significant internal functional and operational reorganization was implemented at the CNBV in 2001. Most significant in this regard was the establishment of a quality control structure to ensure standardization with a uniform exam methodology and procedures for examination of bank and nonbank entities. The lack of exit meetings immediately following examinations made it necessary for banks to wait for the examination report prior to correcting deficiencies. The new electronic work papers that mandate minutes of exit meetings with management are included to ensure that all findings of the examination are discussed prior to the issuance of the formal examination report.

\section{Main Findings}

14. Mexico has significantly improved its compliance with the 25 Basel Core Principles. In 2001 Mexico was noncompliant or materially noncompliant with 6 Core Principles and fully compliant with 12 principles. In 2005 Mexico was noncompliant with 1 principle and fully compliant with 19 principles. This improvement is due to the overall coordinated effort of all the regulatory authorities in formulating and pushing through for enactment a series of laws and regulations to improve banking supervision and regulation. The major issue (Principle 1) is the lack of an autonomous supervisory agency that has the power to control 
all the activities from the inception through the demise of a financial institution including all its nonbank subsidiaries. This hinders comprehensive consolidated supervision especially when many of the financial institutions can outsource many of their activities to jurisdictions outside of Mexico without the approval or supervision of the CNBV.

15. Significant improvements have resulted from the internal restructuring within the CNBV since 2001. Of particular significance is the ongoing contact with supervised entities with the perception that management of the CNBV is characterized as "attentive and approachable." The most significant reform was the implementation of a quality control structure to ensure standardization in the way examinations are conducted. A standardized On/Offsite Examination Manual utilizing both internationally-recognized best practices and locally-developed best practices set forth a uniform examination methodology and procedures for examination of bank and nonbank entities. Another improvement is the introduction of electronic work papers to automate the rating system, and mandatory exit meetings with banks' management receiving all findings of the examination prior to the issuance of the formal examination report. With the standard for examinations in written format and available on its website, the CNBV began the formation of specialized examiners for information technology, credit review, and anti-money laundering and terrorist financing. The CNBV has sought to attract, train, and retain newly qualified examiners in order to ensure a professional workforce. These new examiners are required to follow the internal CNBV Code of Ethics in the performance of their duties.

16. The main findings of the detailed assessment of the compliance with the Basel Core Principles for Effective Banking Supervision are grouped in seven main categories as follows:

- $\quad$ Objectives, Autonomy, Powers, and Resources (CP 1): The CNBV lacks autonomy and authority to solely control a banking institution from its inception to its demise. The current legislation spreads out the accountability for many of these functions among three regulatory agencies: the SHCP, the BOM, and the CNBV. There is an agreement among authorities regarding the need of a reallocation of powers between financial authorities. The SCHP has started to transfer some of its powers to the CNBV. This process is being carried out gradually and on a sector-by-sector basis. In particular, the new Securities Market Law (December 2005) transfers the licensing process for securities intermediaries from the SHCP to the CNBV. The authorities envisage amendments to the Law of Credit Institutions (LIC) which will carry out the same type of transfer in the case of banks. In practice, the CNBV shares information with other regulatory bodies and performs simultaneous inspections with these agencies. Procedures for the sharing of specific information and the conduct of joint examinations have not been formalized although in practice they exist, but are loosely followed. Despite the lack of formalization for joint examinations, the cooperation between agencies has been highly effective. 
- $\quad$ Licensing and Structure (CPs 2-5): In Mexico banks are classified as those institutions that receive deposits. However, due to the broad definition other institutions and nonbanks have captured funds by not calling these funds a "deposit." The recent legislation that was passed into Law on Popular Savings and Credit broadens the scope of the CNBV's supervision to cover previously unregulated activities, yet some loopholes continue to exist. The licensing authority rests with the SHCP as explained in Principle 1. However, the CNBV with the new Securities Market Law of December 2005 licenses intermediaries in the securities area and is awaiting a revision of the LIC to transfer the licensing process for banks to the CNBV in the near future. Should this reform pass it would mandate that all license applications be reviewed by the CNBV's Board of Directors. Changes in ownership or controlling interests in existing banks must be approved by the SHCP. The CNBV does not have formal authority regarding changes in ownership or controlling interests for banks, however its opinion is given to the SHCP for any changes. In practice the SHCP votes in accordance with the opinion given by the CNBV. The CNBV is requesting amendments to the LIC that would grant the CNBV the authority to control changes in the ownership process in the near future. The CNBV is also working on the reform of the LIC to have a formal authority in the process of approving investments by the banking institutions. In practice the CNBV has a definitive voice by delivering its opinion to the SHCP on each individual applicant. The SHCP has historically followed the opinion of the CNBV in these matters.

- $\quad$ Prudential Regulations and Requirements (CPs 6-15):

- The CNBV supervises the minimum capital requirements and has pushed to significantly increase them to provide a comfortable cushion in the event of a crisis. By strengthening the capital requirements Mexican banks are in accordance with the initial Basel Capital Accord, and positioned to comply with Basel II requirements in the areas of credit and operational risk. All institutions will have the possibility to apply for authorization to use internal models for regulatory purposes. Multinational banks, with the aid of their home offices, are expected to have systems in place to comply with the advanced models for Basel II on schedule.

- In August 2005, a new banking circular (Circular Única de Bancos) set up requirements for prudential regulations governing the credit process by updating the previous regulation for banking institutions. A new corporate structure was established redefining each bank's credit policies. The functions and responsibilities for officers and business areas involved in the credit process were delineated. The credit approval process was modified to ensure that the responsibility stays with the banks' Board of Directors, which is not allowed to delegate it to other bodies within the bank. The credit process was redefined establishing different treatments for the assessment of different types of credit. 
The CNBV at each examination reviews the type of credit and its underwriting methodology, and follows up on deficiencies. The CNBV is empowered to demand the creation of preventive loan-loss provisions for those credits posing irregularities and may decree the suspension of new credits. New provisioning rules have been issued in line with international best practices. The new rules issued in 2004 modified existing ones from 1997 and 2000, which had several flaws. In particular, they were too general, demanding the same set of documentation for all loans, while being inadequate for grasping the details of all kinds of operations. The revamping of the credit rating and provisioning regulations in August 2004 assured that banks could apply internal credit rating methodologies for all types of loans (consumer, mortgage, and commercial); as well as specific credit rating methodologies for loans to states and municipalities, for the estimation of provisions. It also makes use of credit risk mitigation techniques on loans, guarantees, and collateral. It allows the CNBV to have a more accurate classification of loans and provisioning for adequate loan-loss reserves, as well as a requirement of additional provisions for foreclosed assets. Credit to unrated municipalities is penalized through substantially higher loanloss provisioning requirements, than for rated municipalities.

- In 1988 the CNBV was provided with the faculty to rule on risk concentrations within the banking system and established limits to asset and liability concentration, according to their net capital or as a percentage of the total capital of the bank. This legislation was modified in 2005 and limits were established on the concentration of credit risk ( 12 percent) to either individuals or groups of individuals, as a share of basic capital (Tier 1). The new framework codified both, groups and corporate holding companies, into the concept of "common risk" to ensure these two types of ownership structures are included within the 12 percent limit. It also excluded those corporate entities not exposed to both credit and market risks from the concept of "common risk." It allows banks to lend more than 12 percent to a particular group provided it has higher capital levels. The sum of all financing granted to the top three borrowers cannot exceed 100 percent of Tier 1 capital. It also replaced the diversification requirement for liabilities by obligating the reporting of this diversification whenever operations exceed the regulatory limits.

- The general framework for connected lending has been significantly revised. In its monthly reporting to the $\mathrm{CNBV}$, banks must provide an indicator on related party lending. This allows the examiner to compare the indicator to a peer group and review onsite any preferential treatment on loans. All related party lending must have the Board of Directors' approval based on adequate information and be limited to 50 percent of total capital. 
- The CNBV does require that banks perform an analysis of country risk and concentration on their loan portfolios. Its examiners review country risk within their bank's loan portfolios, however the risk is limited to letters of credit issued by banks for their customers. Although regulation and supervisory guidelines are very limited to country and transfer risk, the CNBV's opinion is that these risks are not material and do not deserve special attention. The CNBV indicated that exposure to letters of credit, due from bank accounts, and investments in foreign paper compared to their bank's capital is minimal. The CNBV has no jurisdiction over parallel banks unless a Mexican bank has some ownership interest, which may inhibit supervision on country risk.

- The CNBV utilizes its model and information technology systems for calculating Value at Risk (VAR) in accordance with Basel guidance. Its model tests interest sensibility and stress tests a bank's portfolio utilizing worst case scenarios based on historical data for the Mexican market. Each bank is required to perform tests with their own proprietary VAR models which are then compared to the CNBV's model to ensure that conservative assumptions and results are within an acceptable range. Mexican banks are beginning to gather data on operational losses in order to quantify operational risk under the Basel II guidelines. A banking circular sets the norms for all contingency plans required of Mexican banks that include liquidity and continuity of management. These contingency plans must be approved by their Board of Directors. Further improvement of the onsite examination verification of contingency plans and their implementation is needed. These contingency plans are reviewed at each annual examination for adequacy and testing.

- Since 2003 Mexican banks have been required by law to have in place a comprehensive risk management process with board and senior management oversight. The annual bank examinations conducted by the CNBV review how each bank exercises risk management and ensures appropriate capital is assigned to the corresponding risks.

- In September 2001, the first regulation regarding internal controls for commercial banks was issued with full implementation by June 2002. This Circular under its Title II, Chapter VI, provides a comprehensive regulatory framework for internal controls as well as for internal auditing. It established minimum rules for the implementation of policies and procedures on internal controls, including the segregation of functions and responsibilities, the creation of mechanisms of internal control for their operations, and the planning of internal and external audit programs. In September 2005, this circular was updated to include the current risk environment and issued in accordance with international standards, extending its scope to development banks especially the requirement to retain data on operational risk. The goals were to adequately control operational risk, 
reinforce comptroller and internal audit functions, develop and update information systems, and minimize conflict of interests and clearly define the field of action for all participants. Examiners analyze at each annual examination the corporate governance function and the independence of the audit function, as well as its adequacy. The minutes of the audit committee for the board are reviewed to ensure that the board and senior management have informed the committee of any deficiencies. The external auditor though hired by management must report to both the board and the committee in accordance with the Circular Única de Bancos updated in 2006.

- Mexico instituted anti-money laundering legislation in early 1997. Regulated institutions (banking institutions, money exchange houses, nonbank financial institutions and securities firms) were required to periodically file by electronic means to the SHCP through the CNBV, a report comprising any cash transactions over US $\$ 10,000$, as well as suspicious and worrisome transactions. In January 2004, Mexico reformed the legislation to include additional institutions (money transmitters, auxiliary organizations of credit, and non registered money exchange houses). In May of that same year, the General provisions applicable to all sectors of the financial system were enacted, to establish appropriate customer identification procedures, particularly on politically exposed persons, correspondent banking, beneficial owner and trusts, as well as rules to promote high ethical and professional standards in the financial sector. In May 2005, Mexico further refined the legislation to define the politically exposed person's criteria and include government officials by position. The SHCP has issued a format with a questionnaire for banks to utilize in classifying high-risk customers. Since 2005, the CNBV has implemented a new automated work paper program based on the General provisions enacted in May 2004, on all examinations carried out in banks, which provide ratings on the systems, policies and procedures with regards to anti-money laundering and terrorism financing. During 2006, the CNBV will also implement this program to all regulated financial institutions.

- $\quad$ Methods of Ongoing Supervision (CPs16-20):

- The CNBV's onsite supervision has greatly improved since 2001 partly due to the substantial overhaul of the legal framework that has required banks to set up prudential underwriting standards and credit classifications, internal control systems, risk management systems, and corporate governance. The onsite supervision is conducted at least annually and quarterly for larger banks where these systems are validated and reviewed for appropriate coverage. Internally the CNBV has set up a qualitative directive to review best practices regarding onsite supervision and incorporate these practices in the Supervision Manual, which is continuously updated on the CNBV's intranet for the examiners in the field. The restructuring within the CNBV also defined specific specialties necessary for 
adequate oversight. These specialty areas were formed to coordinate with the onsite examiners and plan the scope of risk focused examinations, in order to issue a consolidated report of examination. The methodology for conducting each examination is therefore standardized. Preplanning before each examination ensures newly identified risks are appropriately reviewed by competent staff. The Circular Única de Bancos mandates that external auditors report to the CNBV the scope of their audits, any adjustments to their accounting, and the management letter given to the bank at the end of the audit. The CNBV has the authority to request work papers and review the audit. In the event of an inadequate audit, the CNBV will issue a report with their concerns directly to the external audit firm's management. The CNBV also has the authority to fine or request removal of a partner for failure to follow legislation or regulations.

- Banks are required to issue monthly financial reports which are reviewed by the CNBV. Prior to issuing this report banks must meet with the CNBV officials who have validated the information. The CNBV meets at a minimum once quarterly with top-tier management to discuss any concerns and this is documented in the examiner's work papers especially in cases where deficiencies may require official sanctions. Minutes of exit meetings after an examination are taken to ensure both parties understand the findings. The CNBV is sometimes in daily contact with the larger institutions when there are significant changes in the monthly or quarterly financial reports.

- The offsite supervision is conducted by the CNBV and the BOM through quarterly bank reporting of financial information. These financial reports are later validated by onsite inspections. The system utilized by both of these supervisors allows offsite supervision on a solo basis by each entity. However, large financial groups whose consolidated financial reports encompass numerous activities require close coordination with other supervisors to ensure all activities are transparent and supervised. The CNBV has the authority to fine and sanction banks for poor information and even bank officials individually.

- Validation of supervisory information is conducted by the CNBV's examination teams consisting of four to six examiners during a two-to-three month period in accordance with the risks and size of the bank. The CNBV is also actively involved in the creation of an oversight framework for external auditors in Mexico.

- Legislation is currently under study by the SHCP with the opinion of the CNBV to ensure full comprehensive consolidated supervision. However, although current legislation allows adequate supervision, there is a distribution of duties between several regulators. Bank licensing and supervision are under different regulators 
for the banking industry, whereas both functions are under one regulator for the securities industry.

- Information Requirement (CP 21): The CNBV developed regulatory accounting standards in accordance with international accounting standards; for instance, to prepare consolidated financial statements banks have to include all subsidiaries, whether they are financial entities or not. The CNBV had already issued regulation related to external auditors in 1994 and 2000 (Circulars 1222 and 1479).

Modifications were issued in April 2005 as a result of changes in the best practices of international regulation (such as Sarbanes-Oxley). The definition of "independence" was updated and revised. Specific guidelines regarding requirements for independence apply to external auditors and their offices (e.g., audit partner rotation shall not be longer than five years). Providing additional services other than auditing are limited from the same firm such as bookkeeping or other services related to accounting records, design and implementation of financial information systems, appraisal or valuation services, internal audit services, and some legal services.

- $\quad$ Formal Powers of Supervisors (CP 22): The new Circular Única de Bancos establishes an early warning system. In addition, the CNBV provides information over its website by rating the banks' capital levels in five categories. These capital levels are in accordance with the standards set by the BOM and the regulations set forth by the SHCP. The system was tested in 2004 when a bank's capital fell below the authorized capital level due to derivatives trading. The BOM took immediate action the same day to ensure capital levels at the bank returned to authorized levels. In November 2004, the CNBV issued the "Reglas de Caracter General a que se refiere el Articulo 134 Bis de la Ley de Instituciones de Crédito," which provides the framework under which PCA is undertaken.

\section{- $\quad$ Cross-Border Banking (CPs 23-25):}

- The CNBV continues to supervise Mexican subsidiaries, agencies, and branches abroad with its ongoing review of each bank's strategic plan under the Circular Unica de Bancos. Difficulty is noted in the structures set up by Mexican individuals that basically form parallel banks in other jurisdictions without the knowledge of the CNBV. Although the shareholders are the same, the bank is set up in a foreign jurisdiction where the CNBV has no authority and legislation has not been granted that gives the CNBV extraterritorial powers to investigate shareholders in other jurisdictions. When the foreign financial institution is owned by a bank holding company, the CNBV has the authority to request financial information to satisfy its concerns. Currently Mexican banks are performing dataprocessing functions for foreign subsidiaries and the CNBV has the authority to review the process. However, outsourcing to entities outside of Mexico may cause problems for the CNBV in the future. 
- The CNBV maintains a dialog with home country supervisors of all foreign banks represented in Mexico. Primarily the supervisors of the U.S., Canada, and Spain regularly visit the CNBV annually and discuss mutual concerns. Joint examinations with foreign supervisory entities are permitted with advance notice and provided that a Memorandum of Understanding (MOU) with that foreign supervisor is in place prior to the examination.

- The CNBV has signed bilateral MOUs with 12 foreign bank regulatory agencies and is currently negotiating six more primarily with the authorities of Central American countries. The 12 MOUs are primarily with supervisors of the major banking institutions with subsidiaries in Mexico. The CNBV has also signed 32 MOUs with securities regulatory agencies abroad. 


\section{Table 1. Detailed Assessment of Compliance of the Basel Core Principles for Effective Banking Supervision}

\begin{tabular}{|c|c|}
\hline \multirow[t]{2}{*}{ Principle 1.} & Objectives, autonomy, powers, and resources \\
\hline & $\begin{array}{l}\text { An effective system of banking supervision will have clear responsibilities and objectives for each } \\
\text { agency involved in the supervision of banks. Each such agency should possess operational } \\
\text { independence and adequate resources. A suitable legal framework for banking supervision is also } \\
\text { necessary, including provisions relating to authorization of banking establishments and their } \\
\text { ongoing supervision; powers to address compliance with laws as well as safety and soundness } \\
\text { concerns; and legal protection for supervisors. Arrangements for sharing information between } \\
\text { supervisors and protecting the confidentiality of such information should be in place. }\end{array}$ \\
\hline Description & $\begin{array}{l}\text { The National Banking and Securities Commission (CNBV) lacks autonomy and authority to } \\
\text { solely control a banking institution from its inception to its demise. The current legislation spreads } \\
\text { out the accountability for many of these functions among three regulatory agencies: the } \\
\text { Secretariat of Finance and Public Credit (SHCP), the Bank of Mexico (BOM), and the CNBV. } \\
\text { Also, procedures for the sharing of specific information and the conduct of joint examinations } \\
\text { have not been formalized although in practice they exist, but are loosely followed. }\end{array}$ \\
\hline Assessment & Noncompliant. \\
\hline \multicolumn{2}{|l|}{ Comments } \\
\hline Principle 1(1). & $\begin{array}{l}\text { An effective system of banking supervision will have clear responsibilities and objectives for each } \\
\text { agency involved in the supervision of banks. }\end{array}$ \\
\hline \multirow[t]{4}{*}{ Description } & $\begin{array}{l}\text { At the time of the } 2001 \text { FSAP, the CNBV did not have the core functions to exercise an effective } \\
\text { supervision of banks, nor did it have all the power in the area of regulations. In both areas, the } \\
\text { SHCP had significant power. The division of labor between the CNBV and the SHCP at that time } \\
\text { resulted in some confusion as to the accountability of the different agencies. Similarly, the role of } \\
\text { the CNBV vis-à-vis the Institute of Protection of Banking Savings (IPAB) was not very clear as } \\
\text { both agencies played a role in bank resolution with overlapping responsibilities. The lack of clarity } \\
\text { regarding the role and responsibilities assigned to each agency involved in supervision hindered } \\
\text { cooperation, all the more so since the mechanisms for such cooperation had not been set out in } \\
\text { writing. The agencies had established some formal information sharing mechanisms (Acuerdo de } \\
\text { Intercambio de Información) and also relied on informal contacts for exchanging information and } \\
\text { for discussing the actions to be taken, which did not prove to be fully effective. The key } \\
\text { recommendations of the } 2001 \text { FSAP team included: }\end{array}$ \\
\hline & $\begin{array}{l}\text { 1. Streamlining and clarifying the division of labor between the CNBV, the IPAB, and the SHCP. } \\
\text { Even though it was recognized that public authorities could be involved in the licensing process in } \\
\text { view of the issues at stake-such as financial sector soundness and level playing field- the team } \\
\text { recommended giving consideration to empowering the CNBV with the full licensing authority. It } \\
\text { also noted that the responsibility for issuing prudential regulations should fully rest with the CNBV } \\
\text { in view of its expertise and role as the leading organization for supervisory purposes. As other } \\
\text { authorities are represented on the CNBV's board, their viewpoints regarding regulations and } \\
\text { licensing would be considered. }\end{array}$ \\
\hline & $\begin{array}{l}\text { 2. Amending the composition of the board of the CNBV with the aim of granting more } \\
\text { independence to the CNBV (reducing the number of the SHCP's representatives) and enhancing } \\
\text { cooperation with the IPAB (which was not represented). }\end{array}$ \\
\hline & $\begin{array}{l}\text { 3. Strengthening the mechanisms for addressing problem banks. The Prompt Corrective Action } \\
\text { (PCA) system would lead to a more efficient interaction between the CNBV's duties and IPAB's } \\
\text { responsibilities, and eventually to a more effective framework for bank resolution. However, it was } \\
\text { noted that the adoption of the PCA should be considered only if there was sufficient evidence to } \\
\text { believe that the CNBV would be capable of enforcing, free of political interference, the prescribed } \\
\text { actions when trigger points were reached, and that the adoption of such a system should be delayed }\end{array}$ \\
\hline
\end{tabular}




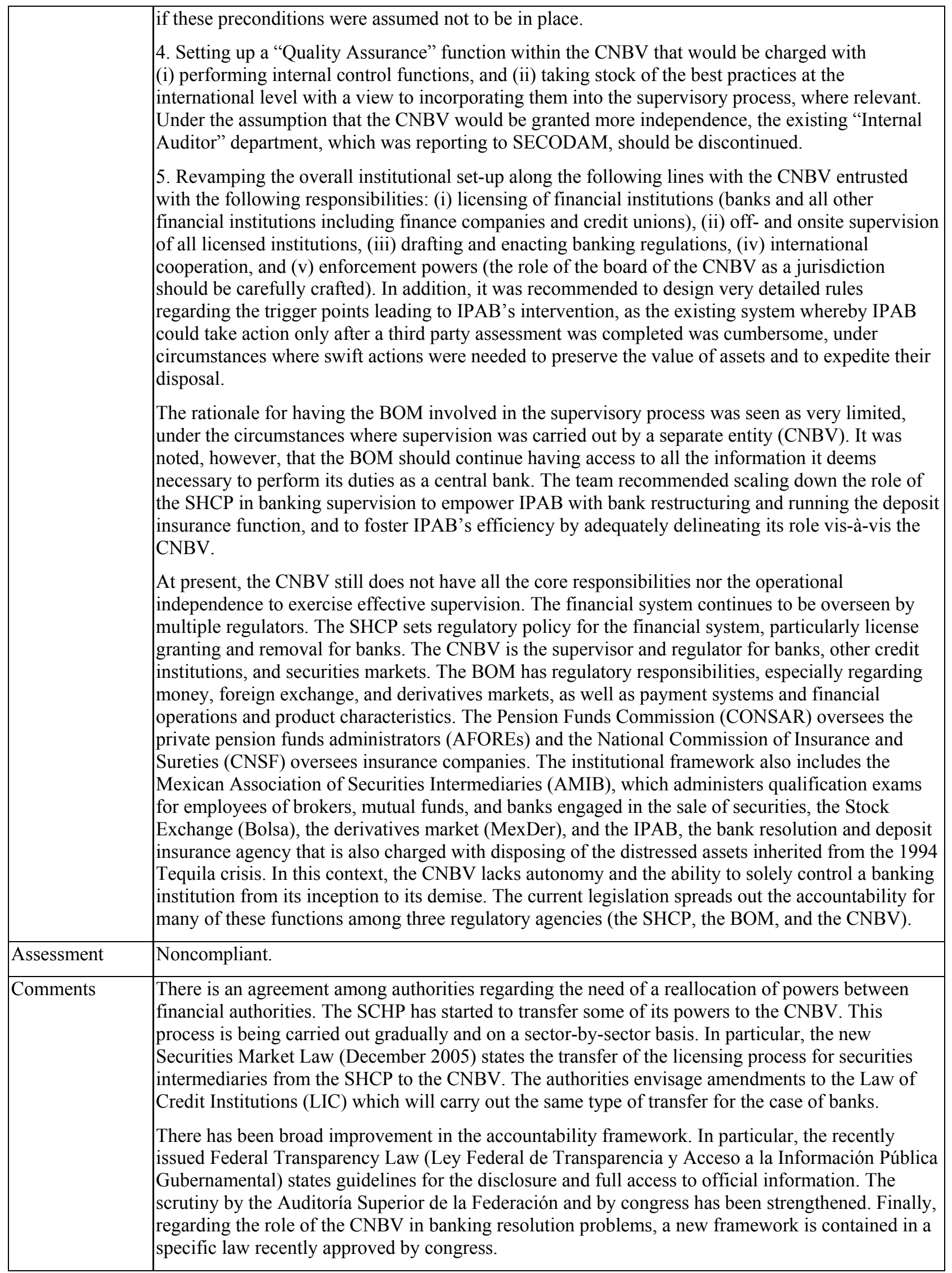




\begin{tabular}{|c|c|}
\hline & $\begin{array}{l}\text { A new Article (134) in the LIC established the basis of the CNBV's system of Prompt Corrective } \\
\text { Actions (PCA) in line with best international practices. In December 2004, the CNBV issued the } \\
\text { Reglas de Carácter General a que se refiere el Articulo } 134 \text { Bis de la ley de Instituciones de Crédito } \\
\text { which provide the general framework for the PCA. } \\
\text { To enhance quality control procedures, a new unit inside the CNBV has been created, the Dirección } \\
\text { General de Métodos, Procesos y Calidad, aiming to standardize CNBV supervisory activities } \\
\text { (including procedures, timeframes, and methodologies) carried out by different supervisory teams. } \\
\text { In 2002, the CNBV adopted an international process for assessing the quality of its core functions } \\
\text { (ISO 9001:2000). }\end{array}$ \\
\hline Principle 1(2). & Each such agency should possess operational independence and adequate resources. \\
\hline Description & $\begin{array}{l}\text { At the time of the 2001 FSAP, political interference in decision-making and budgetary issues } \\
\text { appeared to undermine the operational independence of the CNBV. There was no compliance with } \\
\text { this principle due to the lack of legal protection for supervisors, lack of independence in budgetary } \\
\text { formulation and execution, weak institutional stature, and the appointment of its head by the } \\
\text { Secretary of Finance without specific reasons for his or her removal. In addition, CNBV senior staff } \\
\text { could be removed at the discretion of the President of the CNBV, which may undermine the } \\
\text { independence of their technical work. Efforts were underway to achieve compliance with this } \\
\text { principle. However, to fulfill the objectives of this principle, the CNBV should have had autonomy } \\
\text { with respect to its budget to allocate funds based on its priorities. It was also necessary to grant legal } \\
\text { protection for all supervisory staff in the fulfillment of their duties, and the CNBV President should } \\
\text { be appointed for a minimum term without the possibility for the Government to dismiss him or her, } \\
\text { except for reasons established by law. } \\
\text { At present, although political interference in budgetary issues cannot be excluded, the CNBV has } \\
\text { improved its basis for charging supervised institutions for supervision. The SHCP receives the } \\
\text { proceeds of quotas imposed on the banking sector and disburses approximately } 80 \text { percent to cover } \\
\text { the CNBV's overall expenses, but the CNBV does not have budgetary discretion. } \\
\text { Regarding supervisory protection, on June } 20,2005 \text {, a new article (Article } 21 \text { ) was added to the } \\
\text { National Banking and Securities Commission Law (the CNBV's Law) regarding assistance and } \\
\text { legal protection to CNBV officers when performing their supervisory duties according to their } \\
\text { responsibilities. } \\
\text { In addition, on April } 10,2003 \text {, a new law "Ley del Servicio Profesional en la Administración } \\
\text { Pública Federal" was enacted. It brings the CNBV into the Federal Civil Service and constitutes the } \\
\text { framework for hiring and removal of staff. The law covers positions raging from section chief to } \\
\text { Director General. }\end{array}$ \\
\hline Assessment & Largely compliant. \\
\hline Comments & $\begin{array}{l}\text { Since 2000, the CNBV reports that it has received adequate operating budgets, albeit at levels that } \\
\text { are less than the fees collected for regulation. The staff indicated that the budget is sufficient to staff } \\
\text { all functions adequately, although with somewhat fewer professionals than they believe necessary. } \\
\text { Computer resources appear adequate. In the past five years, the budget issue does not appear to have } \\
\text { resulted in a material limitation on the CNBV. However, the ability of the SHCP to restrict the } \\
\text { CNBV budget creates a potential for future limitations to be imposed on resources. This uncertainty } \\
\text { is the basis for the materially compliant, rather than a compliant assessment. } \\
\text { As noted, the new Law on Professional Service in the Federal Administration brought the CNBV } \\
\text { into the Federal Civil Service and constituted a framework for the hiring and removal of personnel. } \\
\text { Education, past performance, and examinations covering technical expertise, management, and } \\
\text { strategic decision making are requirements for hiring and promotion. Newly hired examiners can } \\
\text { pursue a professional career. }\end{array}$ \\
\hline Principle 1(3). & $\begin{array}{l}\text { A suitable legal framework for banking supervision is also necessary, including provisions } \\
\text { relating to the authorization of banking establishments and their ongoing supervision. }\end{array}$ \\
\hline
\end{tabular}




\begin{tabular}{|c|c|}
\hline Description & $\begin{array}{l}\text { The } 2001 \text { FSAP team recommended that the licensing authority should rest with the supervisory } \\
\text { authority, the CNBV, since it would lessen the impact of political interference and would allow the } \\
\text { CNBV a preliminary examination of a bank prior to opening. It also noted that the rules for capital } \\
\text { adequacy, as well as all prudential regulation, should be formulated and enacted by the supervisory } \\
\text { authority, the CNBV, in view of its specific expertise and its role as supervisory authority. } \\
\text { While the SHCP has actual responsibility for licensing banks and final authority over the CNBV, it } \\
\text { appears that the SHCP does not interfere with the routine duties of the CNBV. Although the legal } \\
\text { framework does not give the CNBV licensing authority which rests with SHCP, in practice the } \\
\text { CNBV has a definitive voice by delivering their opinion to the SHCP on each individual applicant. } \\
\text { The SHCP has followed the opinion of the CNBV on these matters. } \\
\text { As noted, a new unit has been created in the CNBV, the "Dirección General de Métodos, Procesos y } \\
\text { Calidad," aimed at standardizing the CNBV supervisory activities (including, procedures, } \\
\text { timeframes, and methodologies) carried out by the different supervisory teams. In addition, the } \\
\text { CNBV adopted (in 2002) an international process for assessing the quality of its core functions (ISO } \\
9001: 2000 \text { ). }\end{array}$ \\
\hline Assessment & Compliant. \\
\hline Comments & \\
\hline Principle 1(4). & $\begin{array}{l}\text { A suitable legal framework for banking supervision is also necessary, including } \ldots \text { powers to } \\
\text { address compliance with laws as well as safety and soundness concerns. }\end{array}$ \\
\hline Description & $\begin{array}{l}\text { At the time of the 2001 FSAP, the legal framework empowered the CNBV to address compliance } \\
\text { with laws and regulations and banking soundness issues. However, an excess of discretion and } \\
\text { unclear legal support was hindering the CNBV's ability to take remedial action in a timely fashion. } \\
\text { A legislative reform established a system of PCA. A new article (134) in the LIC established the } \\
\text { basis of the CNBV's system of PCA in line with best international practices. In December 2004, the } \\
\text { CNBV issued the Reglas de Carácter General a que se refiere el artículo } 134 \text { Bis de la ley de } \\
\text { Instituciones de Crédito. These rules provide the general framework for the PCA. } \\
\text { A series of other regulatory provisions have been issued aimed at reducing the risk of discretion. } \\
\text { These include: (i) a Supervisory Handbook which establishes the framework guidelines for the } \\
\text { conduct of offsite and onsite supervision; and (ii) the CNBV's Internal Handbook which defines the } \\
\text { roles and responsibilities of CNBV departments and senior officers. }\end{array}$ \\
\hline Assessment & Compliant. \\
\hline Comments & $\begin{array}{l}\text { The new Article } 134 \text { of the LIC and the Reglas de Caracter General that supplements the noted } \\
\text { Article } 134 \text { establish the basis on which the CNBV implements PCA. In addition, the Supervisory } \\
\text { Handbook dictates trigger points when a bank's capital structure could be impaired and requires } \\
\text { immediate action under Article } 220 \text { of the LIC. The recent approval of a new legal framework for } \\
\text { bank resolution is a significant step forward, but aspects concerning the resolution of "too-big-to- } \\
\text { close" banks need close attention. In particular, banks' statutes should be amended as soon a } \\
\text { possible to enable the so-called "conditioned capital restoration plan" and suitable internal } \\
\text { regulations and guidelines need to be developed with regard to the determination of the size of the } \\
\text { haircut to be applied to uninsured creditors. A legal reform of the bank liquidation framework is } \\
\text { pending. }\end{array}$ \\
\hline Principle 1(5). & $\begin{array}{l}\text { A suitable legal framework for banking supervision is also necessary, including... legal protection } \\
\text { for supervisors. }\end{array}$ \\
\hline Description & $\begin{array}{l}\text { The } 2001 \text { FSAP team recommended that the CNBV's legal department put forward a proposal for a } \\
\text { system of adequate legal protection for its supervisors, especially after the supervisors have left } \\
\text { office. The definition of "good faith" needed also to be defined at the time of the } 2001 \text { FSAP. The } \\
\text { team recommended the formulation of a law aimed at adequately funding a reserve for the legal } \\
\text { costs of supervisors defending their actions in discharging their duties. Budgetary inclusion of a } \\
\text { reserve for legal expense costs was seen as essential to ensure coverage of the supervisor's legal }\end{array}$ \\
\hline
\end{tabular}




\begin{tabular}{|c|c|}
\hline & $\begin{array}{l}\text { exposures. } \\
\text { On June 20, 2005, a new article (Article 21) was added to the CNBV's Law regarding assistance } \\
\text { and legal protection to CNBV officers when performing their supervisory duties according to their } \\
\text { responsibilities. }\end{array}$ \\
\hline Assessment & Compliant. \\
\hline Comments & $\begin{array}{l}\text { The CNBV addressed the problem of legal protection and assistance to CNBV supervisors in the } \\
\text { performance of their supervisory duties. The legal protection afforded to supervisors that act in } \\
\text { good faith in the performance of their duties has improved significantly through the passage of the } \\
\text { noted new Article } 21 \text { of the CNBV's Law. A legal fund was set up in a trust with the development } \\
\text { bank Nacional Financiera (NAFIN) to cover CNBV Directors through Department Managers. } \\
\text { However, the fund covers only the costs of legal defense. } \\
\text { As noted, on April 10, 2003, a new law was enacted Ley del Servicio Profesional en la } \\
\text { Administración Pública Federal. This Law brings the CNBV into the Federal Civil Service and } \\
\text { constitutes the framework for hiring and removal of staff in positions ranging from Section Chief to } \\
\text { Director General. A series of other regulatory provisions have been issued aimed at diminishing the } \\
\text { risk of discretional procedures and actions. These include a Supervisory Handbook that establishes } \\
\text { the framework and guidelines for conducting offsite and onsite supervision, and an Internal } \\
\text { Handbook that defines the roles and responsibilities of CNBV departments and senior officers. }\end{array}$ \\
\hline Principle 1(6). & $\begin{array}{l}\text { Arrangements for sharing information between supervisors and protecting the confidentiality of } \\
\text { such information should be in place. }\end{array}$ \\
\hline Description & $\begin{array}{l}\text { The } 2001 \text { FSAP team noted that the existing mechanisms for sharing information at the domestic } \\
\text { level could permit adequate cooperation between supervisory agencies. However, in practice, the } \\
\text { agencies involved in financial sector supervision (the CNBV, CONSAR, the IPAB, and the CNSF) } \\
\text { did not cooperate very closely, nor did they exchange all the information they needed to perform } \\
\text { their duties efficiently. Legislative amendments had been recently introduced to allow for } \\
\text { international cooperation. } \\
\text { At present, powers to exchange information are stated in the CNBV's Law, the LIC, the Securities } \\
\text { Market Law, the Mutual Funds Law, and the CNBV's governing provisions. The CNBV has signed } \\
\text { several MOUs with other supervisory authorities. }\end{array}$ \\
\hline Assessment & Noncompliant. \\
\hline Comments & $\begin{array}{l}\text { In practice, the CNBV shares information with other regulatory bodies and performs simultaneous } \\
\text { inspections with these agencies. Procedures for the sharing of specific information and the conduct } \\
\text { of joint examinations have not been formalized although in practice they exist, but are loosely } \\
\text { followed. Despite the lack of formalization for joint examinations, the cooperation between } \\
\text { agencies has been highly effective. }\end{array}$ \\
\hline Principle 2. & $\begin{array}{l}\text { Permissible activities } \\
\text { The permissible activities of institutions that are licensed and subject to supervision as banks must } \\
\text { be clearly defined, and the use of the word "bank" in names should be controlled as far as } \\
\text { possible. }\end{array}$ \\
\hline Description & $\begin{array}{l}\text { In the view of the } 2001 \text { FSAP team, the definition of a proper banking deposit was the determining } \\
\text { factor in whether Mexico was in compliance with this principle. The LIC only specified that bank } \\
\text { deposits were to be exclusively handled by banks, however, due to a broad definition other } \\
\text { institutions had captured funds by not calling those funds a deposit. } \\
\text { Article } 105 \text { of the Law of Credit Institutions defines and restricts the use of the word "bank" in any } \\
\text { language to banking entities only. Article } 2 \text { and Article } 46 \text { of the LIC define permissible activities } \\
\text { for licensed banks in Mexico. The BOM Circular } 2019 \text { also defines activities for supervised banks. } \\
\text { Article } 2 \text { of the LIC reserves the taking of deposits to institutions that are licensed and subject to } \\
\text { supervision. The recent passing of the Law on Popular Savings and Credit broadened the scope of }\end{array}$ \\
\hline
\end{tabular}




\begin{tabular}{|c|c|}
\hline & regulation and supervision of the CNBV in order to cover previously unregulated activities. \\
\hline Assessment & Compliant. \\
\hline \multicolumn{2}{|l|}{ Comments } \\
\hline \multirow[t]{2}{*}{ Principle 3.} & 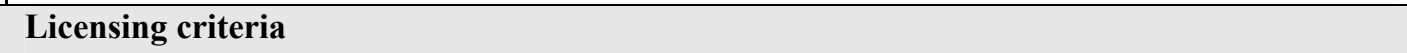 \\
\hline & $\begin{array}{l}\text { The licensing authority must have the right to set criteria and reject applications for } \\
\text { establishments that do not meet the standards set. The licensing process, at a minimum, should } \\
\text { consist of an assessment of the banking organization's ownership structure, directors and senior } \\
\text { management, its operating plan and internal controls, and its projected financial condition, } \\
\text { including its capital base; where the proposed owner or parent organization is a foreign bank, the } \\
\text { prior consent of its home country supervisor should be obtained. }\end{array}$ \\
\hline \multirow[t]{2}{*}{ Description } & $\begin{array}{l}\text { The } 2001 \text { FSAP team noted that the CNBV should have licensing empowerment given its technical } \\
\text { expertise for assessing sound banks, proper bankers, and adequate corporate structures to exercise } \\
\text { banking supervision. }\end{array}$ \\
\hline & 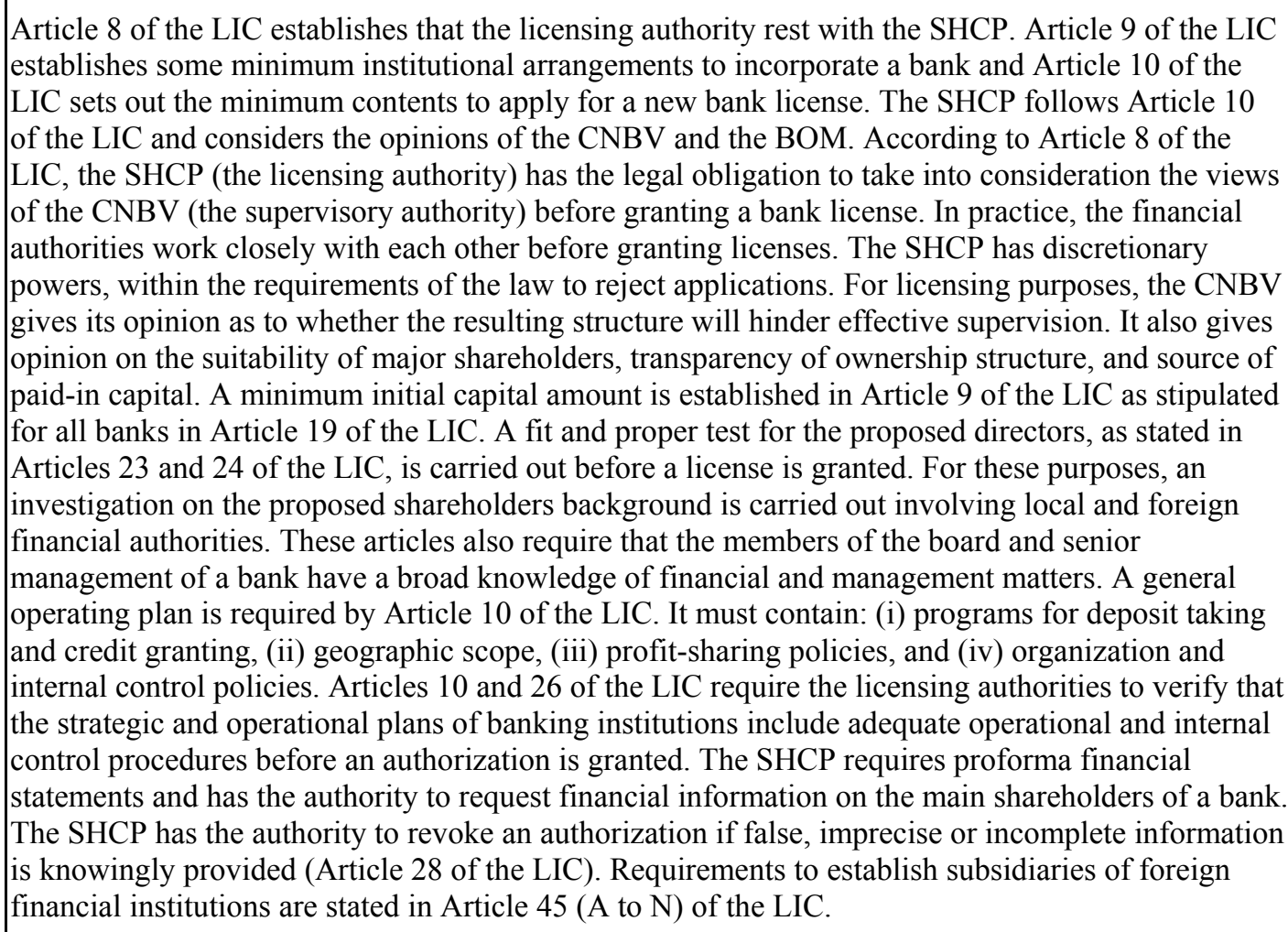 \\
\hline Assessment & Compliant. \\
\hline Comments & $\begin{array}{l}\text { The licensing authority rests with the SHCP. However, the CNBV licenses intermediaries in the } \\
\text { securities area since the passing of the new Securities Market Law in December } 2005 \text {. Amendments } \\
\text { to the LIC are under consideration which would transfer the licensing authority for banking } \\
\text { institutions to the CNBV in the near future. Should the noted amendments pass, it would mandate } \\
\text { that all license applications be reviewed by the CNBV's Board of Directors. }\end{array}$ \\
\hline \multirow[t]{2}{*}{ Principle 4.} & Ownership \\
\hline & $\begin{array}{l}\text { Banking supervisors must have the authority to review and reject any proposals to transfer } \\
\text { significant ownership or controlling interests in existing banks to other parties. }\end{array}$ \\
\hline Description & $\begin{array}{l}\text { The } 2001 \text { FSAP team recommended the CNBV to play a more active role in reviewing and } \\
\text { authorizing proposals to transfer significant ownership or controlling interests because of its }\end{array}$ \\
\hline
\end{tabular}




\begin{tabular}{|c|c|}
\hline & $\begin{array}{l}\text { technical expertise on assessing banks and the quality of their management. } \\
\text { At present, the SHCP's approval is required when a bank seeks to acquire more than } 5 \text { percent of the } \\
\text { equity capital of another bank (Article } 17 \text { of the LIC). The SHCP will take into consideration the } \\
\text { opinions of the CNBV and the BOM. In addition, according to Article } 14 \text { of the LIC, any person } \\
\text { who wishes to purchase or sell equities representing more than } 2 \text { percent of the paid-in capital of a } \\
\text { bank must notify such purchase or sale to the SHCP within the following three working days after } \\
\text { the transaction takes place. }\end{array}$ \\
\hline Assessment & Compliant. \\
\hline Comments & $\begin{array}{l}\text { Changes in ownership or controlling interests in existing banks must be approved by the SHCP. The } \\
\text { CNBV does not have the formal authority to approve the transfer of significant ownership or } \\
\text { controlling interest in existing banks to other parties. However, the SHCP has to request the opinion } \\
\text { of the CNBV for any such changes. In practice, the SHCP votes in accordance with the opinion } \\
\text { given by the CNBV. Amendments to the LIC are under consideration which would provide the } \\
\text { CNBV with the authority to review and reject any proposals to transfer significant ownership or } \\
\text { controlling interests in existing banks to other parties. }\end{array}$ \\
\hline Principle 5. & $\begin{array}{l}\text { Investment criteria } \\
\text { Banking supervisors must have the authority to establish criteria for reviewing major acquisitions } \\
\text { or investments by a bank and ensuring that corporate affiliations or structures do not expose the } \\
\text { bank to undue risks or hinder effective supervision. }\end{array}$ \\
\hline Description & $\begin{array}{l}\text { At the time of the } 2001 \text { FSAP, the CNBV, as the main authority responsible for banking } \\
\text { supervision, was not involved in the review of a bank's investment in the case that an approval was } \\
\text { required in view of its importance. The FSAP team noted that this responsibility should rest with the } \\
\text { CNBV or, at a minimum, the CNBV's opinion should be requested. } \\
\text { Limits on investments by banking institutions in nonfinancial firms are established in Article } 75 \text { of } \\
\text { the LIC. Banks are allowed to acquire up to } 5 \text { percent of a company's paid-in capital without having } \\
\text { to require approval. For investments representing between } 5 \text { percent and } 15 \text { percent of the paid-in- } \\
\text { capital, the securities cannot be held for longer than three years. After approval by the majority of } \\
\text { the members of a bank's Board of Directors, the approval of the SHCP is required for such an } \\
\text { investment if the bank were to decide to keep the securities for longer than three years. Approval by } \\
\text { the SHCP (with the nonbinding opinion of the BOM) is required for investments more than } 15 \\
\text { percent of a company's paid-in capital and for investments that are to be kept for longer than three } \\
\text { years. The sum of a bank's investments in nonfinancial institutions shall not exceed } 5 \text { percent of the } \\
\text { bank's deposit base. Article } 88 \text { of the LIC states that all investments in, and acquisitions of, } \\
\text { companies that provide ancillary services require approval by the SHCP. Article } 89 \text { of the LIC } \\
\text { states that all investments in financial companies registered abroad, regardless of their amount, } \\
\text { require approval by the SHCP. }\end{array}$ \\
\hline Assessment & Largely compliant. \\
\hline Comments & $\begin{array}{l}\text { Amendments to the LIC are under consideration to allow the CNBV to have formal authority in the } \\
\text { process of approving major acquisitions or investments by the banking institutions. However, in } \\
\text { practice the CNBV has currently a definitive voice by delivering its opinion to the SHCP on each } \\
\text { individual applicant. The SHCP has historically followed the opinion of the CNBV in these matters. }\end{array}$ \\
\hline Principle 6. & $\begin{array}{l}\text { Capital adequacy } \\
\text { Banking supervisors must set minimum capital requirements for banks that reflect the risks the } \\
\text { bank undertakes, and must define the components of capital, bearing in mind its ability to absorb } \\
\text { losses. For internationally active banks, these requirements must not be less than those established } \\
\text { in the Basel Capital Accord. }\end{array}$ \\
\hline Description & $\begin{array}{l}\text { At the time of the } 2001 \text { FSAP, efforts were under way to achieve full compliance with this } \\
\text { principle. Although the effects of the financial crisis were progressively absorbed, the capitalization } \\
\text { of banks remained an issue for some specific banks. Because of the magnitude of the crisis and its }\end{array}$ \\
\hline
\end{tabular}


systemic effects, the supervisors had allowed banks for several years to operate without adequate capital. At that time, most large banks complied with capital requirements without having to resort to the inclusion of tax-deferred assets, which amounted to a large percentage of capital for only a few banks. The crisis framework (involving the inclusion of tax-deferred assets, and regulatory forbearance) was being progressively dismantled and by 2003 tax-deferred assets were expected not to account for more than 20 percent of capital.

As the 1996 Amendment on capital requirements for market risks was designed for banks operating in G-10 countries, it was difficult to assess the extent to which the Mexican rules on market risks were fully keeping with the Basel recommendations. The customization of the Basel rules to the particular conditions prevailing in Mexico (e.g., volatility) was seen not only to be legitimate but also necessary. In this connection, it was noted that the capital charge for market risks included not only the trading book but also the banking book. Also, regarding foreign exchange risk, the approach used in Mexico (short-hand method) was apparently stricter as the capital was set at 12 percent as opposed to 8 percent. All in all, the regulation on capital, with the caveat on the inclusion of the tax-deferred assets, seemed to be more stringent than the Basel's guidelines, which was certainly an adequate response to the then prevailing market conditions in Mexico.

Although the definition of capital included tax-deferred assets to an extent that was not in keeping with the Basel recommendations (since this element could not absorb losses), the market at large was aware of this peculiarity. The CNBV provided the market with updates on the break down of capital for the major banks. In so doing, the CNBV kept the public informed of the banks' ongoing progress towards beefing up their capital. The CNBV was commended by the FSAP team for having initiated a process that was expected to result in limiting the importance of tax-deferred assets by 2003. The team noted that, as the banking industry at large became more profitable, the CNBV should consider tightening further the limitation on tax-deferred assets.

Since the New capital Accord suggests the adoption of a PCA system (Pillar two) to be implemented in 2004 in G-10 countries, the 2001 FSAP team noted that the prudential authorities should carefully weigh the pros and cons regarding the implementation of such a system before the adoption and implementation of new rules on capital (under the assumption that the Mexican authorities would adopt the Basel framework). If the implementation of a PCA system were to be postponed, this should not prevent the CNBV from tightening its internal procedures with respect to intervention in problem banks. By virtue of the circular on capital, the BOM was entrusted with the power of granting exemptions in exceptional circumstances. Even though the CNBV was supposed to be consulted prior to such decisions being taken, it would make more sense to empower the supervisor who is likely to have a more comprehensive view of the condition of the bank.

At present, the SHCP is the authority to establish the rules on banks' capital requirements. Capitalization Rules for Banking Institutions were issued in 1999 and require banks to calculate a capital adequacy ratio that takes into account both credit and market risks. According to the regulations, banks must maintain a minimum amount of capital that equals the sum of the capital requirements for credit risk and market risk. For credit risk, on- and off-balance sheet items are weighted depending on their presumed riskiness. The methodology used for market risk follows the building blocks approach recommended in the Amendment on Market Risk of the 1988 Basel Capital Accord. The definition of capital is broadly consistent with the Basel recommendations. The Core capital comprises paid-in capital, reserves, and hybrid instruments with noncumulative dividends. Supplementary capital (Tier 2) comprises, among other items, capital instruments with cumulative dividends, subordinate debt, and loan-loss provisions that cannot exceed 1.25 percent of total assets. Tier 2 capital cannot exceed Tier 1 capital in line with the Basel Committee's guidelines. Capital ratios are calculated by the BOM based on the information provided by banks on a monthly basis. In addition, banks are required to disclose comprehensive information regarding their capital at least annually, and quarterly for listed companies. Article 19 of the LIC establishes that the minimum capital for banks shall be at least 0.12 percent of the sum of the overall capital of all banks as measured at the end of each year. The current requirements do not mandate banks to calculate their capital ratio on a consolidated basis. However, banks' investments in financial subsidiaries must be deducted from regulatory capital as prescribed by the 1988 Basel Accord. 


\begin{tabular}{|c|c|}
\hline & $\begin{array}{l}\text { Banks have significantly increased their capitalization ratios and the system has at present a very } \\
\text { comfortable capital cushion. Regulatory capital requirements have been strengthened and the } \\
\text { CNBV is working towards the implementation of the New Capital Accord in line with the timetable } \\
\text { of the Basel Committee on Banking Supervision. }\end{array}$ \\
\hline Assessment & Compliant. \\
\hline Comments & $\begin{array}{l}\text { The CNBV set minimum capital requirements and significantly increased them to provide a } \\
\text { comfortable cushion in the event of a crisis. By strengthening the capital requirements, Mexican } \\
\text { banks are in accordance with the } 1988 \text { Basel Capital Accord, and positioned to comply with Basel II } \\
\text { requirements in the areas of credit and operational risk. The smaller banks are expected to follow } \\
\text { the more basic approaches, however multinational banks with the aid of their home offices will have } \\
\text { systems in place to comply with the advanced models for Basel II on schedule. }\end{array}$ \\
\hline \multirow[t]{2}{*}{ Principle 7.} & Credit policies \\
\hline & $\begin{array}{l}\text { An essential part of any supervisory system is the independent evaluation of a bank's policies, } \\
\text { practices and procedures related to the granting of loans and making of investments and the } \\
\text { ongoing management of the loan and investment portfolios. }\end{array}$ \\
\hline \multirow[t]{5}{*}{ Description } & $\begin{array}{l}\text { In August of } 2005 \text { a new banking circular (Circular Unica de Bancos) was issued establishing } \\
\text { detailed requirements for prudential regulations governing the credit process. It aims at ensuring an } \\
\text { adequate evaluation of banks' policies, practices, and procedures related to the granting of loans and } \\
\text { making of investments and the ongoing management of the loan and investment portfolio. It } \\
\text { delineates the functions and responsibilities for officers and for business areas involved in the credit } \\
\text { process. The credit approval process was modified to ensure the responsibilities of the Board of } \\
\text { Directors, which cannot be delegated to other bodies. The credit process was redefined establishing } \\
\text { different treatments for the assessment of different types of credit. The bank's Board of Directors } \\
\text { can modify and enhance the credit policies. The CNBV's onsite examination teams review } \\
\text { compliance and Board of Director's approval of credit policies and offsite teams conduct further } \\
\text { review in the event of discrepancies. The CNBV reviews the trading portfolio daily and securities } \\
\text { held to maturity on an ongoing basis and annually during onsite examinations. Banks are required to } \\
\text { have an internal risk management committee to review risks involved with all new products } \\
\text { including investment products. }\end{array}$ \\
\hline & $\begin{array}{l}\text { The Circular Unica de Bancos also establishes criteria for selecting investments and the granting of } \\
\text { credits, including the appropriate credit administration and documentation. The CNBV's onsite } \\
\text { teams compare credit file documentation with what is prescribed by the noted Circular Unica. In the } \\
\text { event of repeated credit file discrepancies, the CNBV can sanction the bank with monetary fines. } \\
\text { The loan review process required by this circular also ensures that control mechanisms are in place } \\
\text { to foster safe and sound practices. }\end{array}$ \\
\hline & $\begin{array}{l}\text { The Circular Unica de Bancos also requires that a bank should establish an independent area of } \\
\text { loan control and review in charge of assessing the granting of credit and ensuring that this process is } \\
\text { free from inappropriate pressure from third parties. This area should be free of conflicts of interest } \\
\text { from the credit origination area. Compliance and independence is assessed by the CNBV's onsite } \\
\text { examination teams. Onsite examination teams issue questionnaires to all personnel involved in the } \\
\text { granting of credit to assess whether they have a clear understanding of their responsibilities. }\end{array}$ \\
\hline & $\begin{array}{l}\text { The Circular Unica de Bancos also requires banks to perform, for purposes of loan approval, } \\
\text { sensitivity analysis on projected flows taking into account variations in the risk factors, such as } \\
\text { interest rates and the exchange rate, when the amount of the operation exceeds the lowest of } 10 \\
\text { percent of the bank's capital or the equivalent in domestic currency of UDIs } 30 \text { million. }\end{array}$ \\
\hline & $\begin{array}{l}\text { According to Article } 19 \text { of the CNBV's Law, the CNBV is empowered to have access to all bank } \\
\text { records. }\end{array}$ \\
\hline Assessment & Compliant. \\
\hline Comments & $\begin{array}{l}\text { The CNBV at each examination reviews the type of credit, its underwriting methodology, and } \\
\text { follows up on deficiencies. The CNBV has the authority to demand banks to create preventive loan- }\end{array}$ \\
\hline
\end{tabular}




\begin{tabular}{|c|c|}
\hline & $\begin{array}{l}\text { loss provisions for those credits posing irregularities and may also demand the suspension of new } \\
\text { lending. }\end{array}$ \\
\hline \multirow[t]{2}{*}{ Principle 8.} & Loan evaluation and loan-loss provisioning \\
\hline & $\begin{array}{l}\text { Banking supervisors must be satisfied that banks establish and adhere to adequate policies, } \\
\text { practices, and procedures for evaluating the quality of assets and the adequacy of loan-loss } \\
\text { provisions and reserves. }\end{array}$ \\
\hline \multirow[t]{2}{*}{ Description } & $\begin{array}{l}\text { At the time of the } 2001 \text { FSAP, efforts were underway to achieve full compliance with this principle. } \\
\text { Although prudential regulations on loan classification and provisioning were in line with sound } \\
\text { practices, CNBV representatives pointed out a lack of full implementation basically because a } \\
\text { relevant Circular (Circular 1480) was going to take full effect only in June of } 2001 \text {. Consequently, it } \\
\text { was envisaged that banks would need some time to put them in place. Also, at that time private } \\
\text { market participants indicated that the implementation of CNBV loan classification and provisioning } \\
\text { rules resulted in misclassifications at some banks. The main reason adduced was the weak treatment } \\
\text { of restructured operations. In this connection, the } 2001 \text { FSAP team noted that the CNBV should } \\
\text { consider strengthening the enforcement of a proper treatment for restructured loans. On the other } \\
\text { hand, the CNBV was commended for a proactive policy towards the use of internal ratings as a } \\
\text { means of calculating provision against impaired loans. }\end{array}$ \\
\hline & $\begin{array}{l}\text { New provisioning rules have been issued in line with international best practices. The new rules } \\
\text { issued in } 2004 \text { modified existing ones from } 1997 \text { and } 2000 \text {, which played an important role in the } \\
\text { aftermath of the } 1995 \text { crisis, but had several flaws: mainly they were too general, demanding the } \\
\text { same set of documentation to all loans; and at the same time being incapable of grasping the details } \\
\text { of all kinds of operations. The revamping of the credit rating and provisioning regulations in August } \\
2004 \text { assured that banks could apply internal credit rating methodologies for all types of loans } \\
\text { (consumer, mortgage, and commercial); as well as apply specific credit rating methodologies for } \\
\text { loans to states and municipalities. It also made use of credit risk mitigation techniques on loans, } \\
\text { guarantees, and collateral. It allowed the CNBV to have a more accurate classification of loans and } \\
\text { provisioning for adequate loan-loss reserves, as well as a requirement of additional provisions for } \\
\text { foreclosed assets. Credit ratings for municipalities were required for granting of loans with } \\
\text { substantial loan-loss reserves required for unrated municipalities. }\end{array}$ \\
\hline Assessment & Compliant. \\
\hline Comments & $\begin{array}{l}\text { The new CNBV's provisioning rules have been issued in line with international best practices. They } \\
\text { are compiled in the Circular Unica de Bancos. }\end{array}$ \\
\hline \multirow[t]{2}{*}{ Principle 9.} & Large exposure limits \\
\hline & $\begin{array}{l}\text { Banking supervisors must be satisfied that banks have management information systems that } \\
\text { enable management to identify concentrations within the portfolio and supervisors must set } \\
\text { prudential limits to restrict bank exposures to single borrowers or groups of related borrowers. }\end{array}$ \\
\hline \multirow[t]{2}{*}{ Description } & $\begin{array}{l}\text { At the time of the } 2001 \mathrm{FSAP} \text {, limiting overall exposure to } 15 \text { percent for both individuals and } \\
\text { corporations compared to Tier-I capital was under consideration. A stricter definition of exposure } \\
\text { and closely related group was also under consideration. }\end{array}$ \\
\hline & $\begin{array}{l}\text { In } 1988 \text { the CNBV was provided with the faculty to rule on risk concentrations within the banking } \\
\text { system and established limits to asset and liability concentration, according to their net capital or as } \\
\text { a percentage of the total capital in the banking system. The CNBV modified the legislation in } 2003 \text {, } \\
\text { establishing limits on the concentration of credit risk to either individuals or groups of individuals, } \\
\text { as a function of basic capital (Tier 1). This codified both, groups and corporate holding companies, } \\
\text { into the concept of "common risk," as well as excluded those corporate entities not exposed to both } \\
\text { credit and market risks from the concept of "common risk." It allows banks to lend more than } \\
12 \text { percent to a particular group provided they have higher capital levels. The sum of all financing } \\
\text { granted to the three largest borrowers cannot exceed } 100 \text { percent of a bank's Tier } 1 \text { capital. }\end{array}$ \\
\hline
\end{tabular}




\begin{tabular}{|c|c|}
\hline & The main limits established are indicated in the table below: \\
\hline & Financing limit in terms of Tier 1 capital \\
\hline & More than 8 percent and up to 9 percent \\
\hline & More than 9 percent and up to 10 percent \\
\hline & More than 10 percent and up to 12 percent \\
\hline & More than 12 percent and up to 15 percent \\
\hline & More than 15 percent \\
\hline Assessment & Compliant. \\
\hline Comments & $\begin{array}{l}\text { As noted above, the Circular Única de Bancos compiles in one provision all banking regulations } \\
\text { issued by the CNBV. }\end{array}$ \\
\hline Principle 10. & Connected lending \\
\hline & $\begin{array}{l}\text { In order to prevent abuses arising from connected lending, banking supervisors must have in place } \\
\text { requirements that banks lend to related companies and individuals on an arm's-length basis, that } \\
\text { such extensions of credit are effectively monitored, and that other appropriate steps are taken to } \\
\text { control or mitigate the risks. }\end{array}$ \\
\hline Description & $\begin{array}{l}\text { The } 2001 \text { FSAP mission noted that, to avoid capital inefficiencies, it was worth considering limiting } \\
\text { credits to shareholders not on Tier } 1 \text { capital, but rather on the shareholder's investment. In doing so, } \\
\text { a shareholder could not be given loans that exceed the value of its investment in the bank. }\end{array}$ \\
\hline & $\begin{array}{l}\text { The general framework for connected lending has been significantly revised as established by } \\
\text { Articles } 73,73 \text { bis, and } 73 \text { bis } 1 \text { of the LIC. In its monthly reporting to the CNBV, the bank must } \\
\text { provide an indicator on related lending. This allows the examiner to compare the indicator to a peer } \\
\text { group and review on site any preferential treatment on loans. All related lending must have the } \\
\text { Board of Directors' approval based on adequate information. The total amount of credit to related } \\
\text { parties cannot exceed } 75 \text { percent of a bank's Tier } 1 \text { capital (Article } 73 \text { bis of the LIC). }\end{array}$ \\
\hline Assessment & Largely compliant. \\
\hline Comments & \\
\hline Principle 11. & $\begin{array}{l}\text { Country risk } \\
\text { Banking supervisors must be satisfied that banks have adequate policies and procedures for } \\
\text { identifying, monitoring and controlling country risk and transfer risk in their international lending } \\
\text { and investment activities, and for maintaining appropriate reserves against such risks. }\end{array}$ \\
\hline Description & $\begin{array}{l}\text { At the time of the } 2001 \text { FSAP, regulation and supervisory guidelines were very limited regarding } \\
\text { country and transfer risk, but the CNBV representatives' opinion was that these risks were not } \\
\text { material and did not deserve special attention. } \\
\text { At present, the CNBV does require that banks perform an analysis of country risk and } \\
\text { concentrations. Their examiners review country risk within their bank's portfolios, however, the } \\
\text { risk is limited to letters of credit issued by banks for their customers. This exposure to letters of } \\
\text { credit compared to their bank's capital is minimal. Thus, the CNBV maintains the view that these } \\
\text { risks are not material and do not deserve special attention. The CNBV has no jurisdiction over } \\
\text { parallel banks unless a Mexican bank has some ownership interest, which may inhibit supervision } \\
\text { on country risk. }\end{array}$ \\
\hline Assessment & Compliant. \\
\hline Comments & \\
\hline
\end{tabular}




\begin{tabular}{|c|c|}
\hline Principle 12. & $\begin{array}{l}\text { Market risks } \\
\text { Banking supervisors must be satisfied that banks have in place systems that accurately measure, } \\
\text { monitor, and adequately control market risks; supervisors should have powers to impose specific } \\
\text { limits and /or a specific capital charge on market risk exposures, if warranted. }\end{array}$ \\
\hline Description & $\begin{array}{l}\text { The } 2001 \text { FSAP team recommended further improvement of the onsite verification of contingency } \\
\text { plans and their implementation. } \\
\text { The CNBV utilizes its model and information technology (IT) systems for calculating VAR in } \\
\text { accordance with Basel guidance. Its model tests risk sensitivity (several factors are considered: local } \\
\text { and international interest rates, equities and foreign exchange) and stress tests a bank's portfolio } \\
\text { utilizing worst case scenarios based on historical data for the Mexican market. Each bank is } \\
\text { required to perform tests with their own proprietary VAR models which are then compared to the } \\
\text { CNBV's model to ensure that conservative assumptions and results are within an acceptable range. } \\
\text { The Circular Única de Bancos requires individual banks to have in place comprehensive risk } \\
\text { management processes, including appropriate Board of Directors and senior management oversight. } \\
\text { This circular establishes minimum criteria to identify and control risks, including market risks. The } \\
\text { CNBV is empowered to review and request modifications to limits established by the banks on } \\
\text { foreign exchange, derivatives, capital market products, and all positions held by banks. Through } \\
\text { internal review the CNBV determines that appropriate limits have been set. Within the CNBV, a } \\
\text { Market Risk Committee reviews each analysis on market risks performed on banks and internally } \\
\text { disseminate the review to all members of the examination staff. } \\
\text { The current risk-based capital guidelines issued by the BOM are reviewed by both the CNBV's on- } \\
\text { and offsite examination teams. In conjunction with the BOM, the CNBV can impose specific capital } \\
\text { charges and limits on risk exposures to banks that have weak risk management or risk control } \\
\text { frameworks. } \\
\text { The Circular Única de Bancos sets the norms for contingency plans required of all banks that must } \\
\text { be approved by their Board of Directors. These contingency plans are reviewed at each annual } \\
\text { examination for adequacy and testing. }\end{array}$ \\
\hline Assessment & Compliant. \\
\hline Comments & \\
\hline Principle 13. & $\begin{array}{l}\text { Other risks } \\
\text { Banking supervisors must be satisfied that banks have in place a comprehensive risk management } \\
\text { process (including appropriate board and senior management oversight) to identify, measure, } \\
\text { monitor, and control all other material risks and, where appropriate, to hold capital against these } \\
\text { risks. }\end{array}$ \\
\hline Description & $\begin{array}{l}\text { The Circular Unica de Bancos requires individual banks to have in place comprehensive risk } \\
\text { management processes, including appropriate Board of Directors and senior management oversight. } \\
\text { It states that risk management processes should address credit, market, liquidity, operational, legal, } \\
\text { and other material risks. According to this circular, a bank's Board of Directors must approve risk } \\
\text { exposure limits submitted by the bank's Risk Committee, while the Risk Management Unit must } \\
\text { ensure that the limits are complied with. The CNBV includes in its terms of reference for onsite } \\
\text { visits that limits and procedures are well communicated and observed within a bank. If limits are } \\
\text { exceeded, the bank's risk manager is required to report on this event to the CEO of the bank. The } \\
\text { noted Circular also establishes that disclosure of risk exposures, and risk management policies and } \\
\text { procedures is a formal requirement for banks. } \\
\text { The CNBV has the authority to require additional capital in view of, inter alia, a bank's composition } \\
\text { of assets, efficiency of its internal control systems, and quality of its risk management. This } \\
\text { authority could be used to require capital for risks not explicitly contemplated in the regulation on } \\
\text { capital requirements. }\end{array}$ \\
\hline
\end{tabular}




\begin{tabular}{|c|c|}
\hline Assessment & Compliant. \\
\hline Comments & $\begin{array}{l}\text { Since } 2000 \text {, the Mexican banks have been required by law to have in place a comprehensive risk } \\
\text { management process with board and senior management oversight. The annual bank examinations } \\
\text { conducted by the CNBV reviews how each bank exercises risk management and ensures that } \\
\text { appropriate capital is assigned to the corresponding risks. }\end{array}$ \\
\hline \multirow[t]{2}{*}{ Principle 14.} & Internal control and audit \\
\hline & $\begin{array}{l}\text { Banking supervisors must determine that banks have in place internal controls that are adequate } \\
\text { for the nature and scale of their business. These should include clear arrangements for delegating } \\
\text { authority and responsibility; separation of the functions that involve committing the bank, paying } \\
\text { away its funds, and accounting for its assets and liabilities; reconciliation of these processes; } \\
\text { safeguarding its assets; and appropriate independent internal or external audit and compliance } \\
\text { functions to test adherence to these controls as well as applicable laws and regulations. }\end{array}$ \\
\hline \multirow[t]{4}{*}{ Description } & $\begin{array}{l}\text { At the time of the 2001 FSAP, efforts were underway to achieve compliance with this principle. } \\
\text { During the year 2000, the CNBV had prepared a new piece of regulation on internal control with the } \\
\text { aim of complementing the regulation on risk management (Circular 1423). }\end{array}$ \\
\hline & $\begin{array}{l}\text { This regulation was aimed at ensuring that banks will have segregation of duties, periodic internal } \\
\text { reporting, accurate information systems, and procedures for checking compliance with laws and } \\
\text { regulations. The internal control guidelines would also spell out the responsibilities for all relevant } \\
\text { participants including the Board of Directors, the General Director, and the internal and external } \\
\text { auditors. The guidelines also required the creation of an audit committee with exclusive } \\
\text { participation of members of the Board of Directors, and the preparation and implementation of an } \\
\text { ethic code. }\end{array}$ \\
\hline & $\begin{array}{l}\text { In September 2001, the first regulation regarding internal controls for commercial banks was issued } \\
\text { with full implementation by June } 2002 \text {. It established minimum rules for the implementation of } \\
\text { policies and procedures on internal controls, including the segregation of functions and } \\
\text { responsibilities, the creation of mechanisms of internal control for the banks' operations, and the } \\
\text { planning of internal and external audit programs. }\end{array}$ \\
\hline & $\begin{array}{l}\text { More recently, new regulations have been issued in accordance with international best practices. As } \\
\text { was mentioned before, the Circular Unica de Bancos compiles in one provision all banking } \\
\text { regulations issued by the CNBV. This Circular under its Title II, Chapter VI, provides a } \\
\text { comprehensive regulatory framework for internal controls as well as for internal auditing. It aims at } \\
\text { adequately controlling operational risk, reinforcing comptroller and internal audit functions, } \\
\text { developing and updating information systems, and minimizing conflicts of interest and clearly } \\
\text { defining the field of action for all participants. Examiners analyze at each annual examination the } \\
\text { corporate governance function and the independence of the audit function as well as its adequacy. } \\
\text { The minutes to the audit committee for the board are reviewed to ensure that the board and senior } \\
\text { management have informed the committee of any deficiencies. The external auditor though hired by } \\
\text { management must report to both the board and the committee in accordance with the Circular } \\
\text { Unica de Bancos updated in } 2006 \text {. This recent law also requires the establishment of corporate } \\
\text { governance and a code of ethics for all personnel, as well as an appropriate number of independent } \\
\text { directors within a } 15 \text {-member Board of Directors that includes an audit committee headed by an } \\
\text { independent director. }\end{array}$ \\
\hline Assessment & Compliant. \\
\hline \multicolumn{2}{|l|}{ Comments } \\
\hline \multirow[t]{2}{*}{ Principle 15.} & Money laundering \\
\hline & $\begin{array}{l}\text { Banking supervisors must determine that banks have adequate policies, practices, and procedures in } \\
\text { place, including strict "know-your-customer" rules, that promote high ethical and professional } \\
\text { standards in the financial sector and prevent the bank being used, intentionally or unintentionally, } \\
\text { by criminal elements. }\end{array}$ \\
\hline
\end{tabular}




\begin{tabular}{|c|c|}
\hline Description & 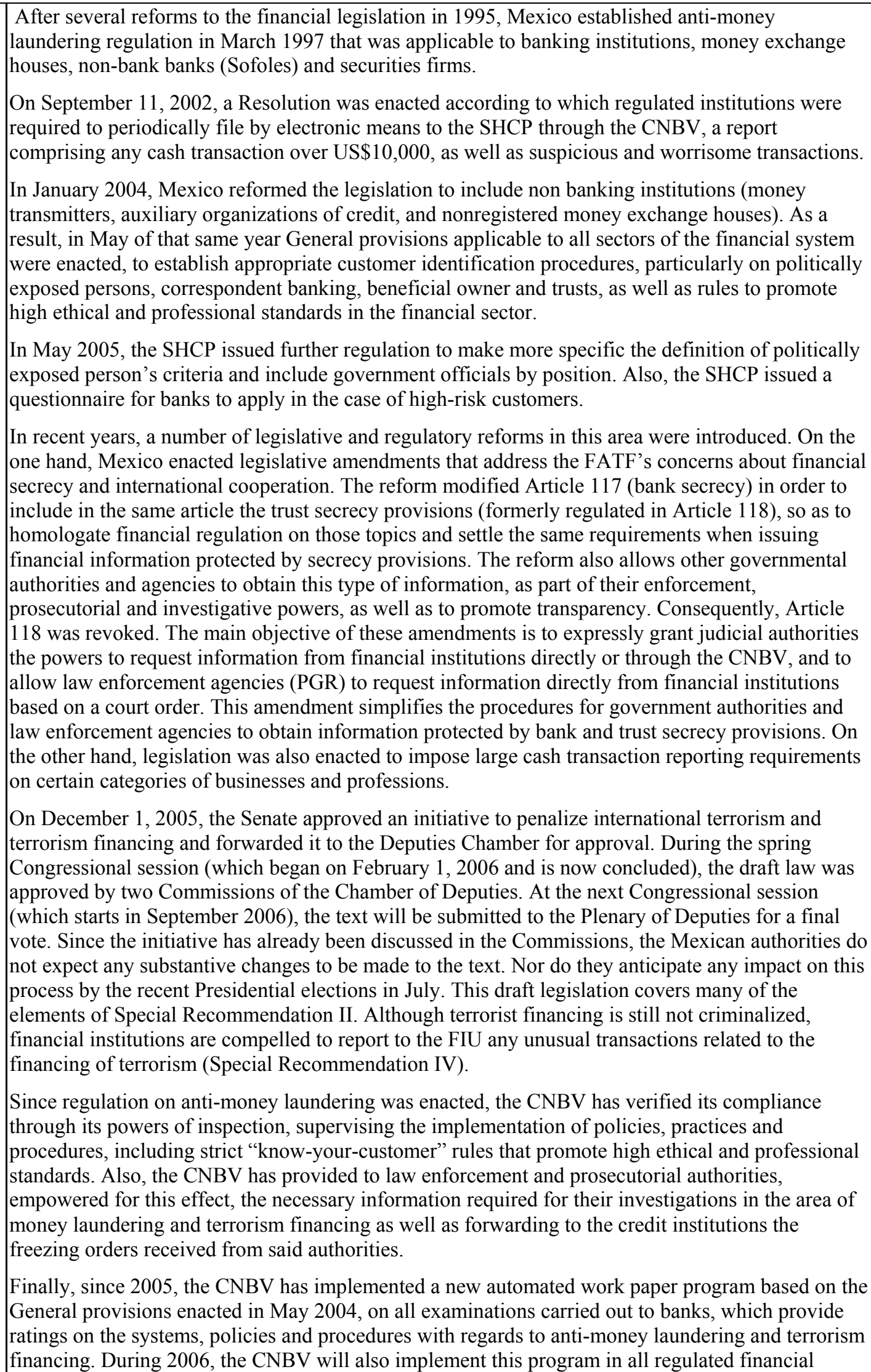 \\
\hline
\end{tabular}




\begin{tabular}{|c|c|}
\hline & institutions. \\
\hline Assessment & Compliant. \\
\hline \multicolumn{2}{|l|}{ Comments } \\
\hline \multirow[t]{2}{*}{ Principle 16.} & Onsite and offsite supervision \\
\hline & $\begin{array}{l}\text { An effective banking supervisory system should consist of some form of both onsite and offsite } \\
\text { supervision. }\end{array}$ \\
\hline \multirow[t]{7}{*}{ Description } & $\begin{array}{l}\text { The } 2001 \text { FSAP team noted that the CNBV had been undertaking major changes over the last few } \\
\text { years with the aim of improving the scope of supervision and the quality of its supervisory tools. As } \\
\text { a result of a substantial overhaul of the legal framework, not only had supervision been enhanced, } \\
\text { but banks had been compelled to improve their risk management systems. The move towards a more } \\
\text { qualitative supervision was reflected in the organizational changes (such as technical departments } \\
\text { which were providing substantial support to supervisors in the area of market risks, risk } \\
\text { management, and supervisory processes) and the enhanced quality of the offsite analysis. However, } \\
\text { in the view of the } 2001 \text { FSAP team, modernization would not be achieved unless the onsite methods } \\
\text { and focus were amended. }\end{array}$ \\
\hline & $\begin{array}{l}\text { There was a need to move towards the adoption of a more risk-focused approach for onsite } \\
\text { examinations which, at the time of the } 2001 \text { FSAP, embraced all the facets of banks' activities } \\
\text { without any prioritization of tasks. It was recognized that during a phase of transition, the CNBV } \\
\text { had been eager to closely monitor a still vulnerable banking system. In this connection, the } \\
\text { inspectors were reviewing in great detail the quality of the loan portfolio and the adequacy of loan- } \\
\text { loss provisions. The } 2001 \text { FSAP team noted that as the effect of the banking crisis faded away going } \\
\text { forward, it would become more crucial for onsite supervisors to concentrate on revealing the major } \\
\text { risks of banks. At that time, however, it seemed that the uneven expertise among onsite examiners } \\
\text { was a major hurdle that the CNBV would need to concentrate on. }\end{array}$ \\
\hline & $\begin{array}{l}\text { The } 2001 \text { FSAP team also noted that, in the absence of forceful decisions towards external auditors } \\
\text { that failed to adequately perform their duties, it would be extremely difficult for the CNBV to expect } \\
\text { a major contribution to the supervisory process from external auditors, irrespective of the merits of } \\
\text { the new regulation. As in other domains, enforcing regulations and especially resorting to sanctions } \\
\text { would be key to shoring up the CNBV's credibility and to ensuring the implementation of sound } \\
\text { practices. }\end{array}$ \\
\hline & $\begin{array}{l}\text { The } 2001 \text { FSAP team recommended that, as a routine procedure, examiners should meet with the } \\
\text { banks' Board of Directors and external auditors so as to exchange views on the results of onsite } \\
\text { examinations annually. In the view of the team at that time, over staffing made it possible for the } \\
\text { CNBV to assemble large teams of inspectors (up to } 50 \text { staff) examining banks for very long periods } \\
\text { of time (up to } 10 \text { months). As the CNBV objective was to examine banks once a year, the prevailing } \\
\text { procedures at the time resulted in supervisors staying in the largest banks almost permanently. The } \\
\text { team recommended the CBNV to urgently take steps to reshuffle the onsite process with the aim of } \\
\text { focusing on the main risks taken by banks. The quality of the offsite process should make it possible } \\
\text { for onsite examiners to concentrate on aspects that are not well captured through the data and reports } \\
\text { submitted by banks. }\end{array}$ \\
\hline & $\begin{array}{l}\text { The } 2001 \text { FSAP mission also recommended the CNBV to put in place a set of incentives to improve } \\
\text { the quality of the onsite supervision. This objective required several conditions, such as raising the } \\
\text { status of onsite supervisors and providing appropriate training. }\end{array}$ \\
\hline & $\begin{array}{l}\text { The CNBV's onsite supervision has greatly improved since } 2001 \text { partly due to the substantial } \\
\text { overhaul of the legal framework that has required banks to set up prudential rating standards and } \\
\text { credit classifications, internal control systems, risk management systems, and corporate governance. } \\
\text { The CNBV has now both Supervisory Provisions (Reglamento de Supervisión) and supervisory } \\
\text { manuals. Methodologies and approaches have been revised. }\end{array}$ \\
\hline & $\begin{array}{l}\text { Also, as noted above, the Circular Única de Bancos compiles in one provision all banking } \\
\text { regulations issued by the CNBV. This Circular under its Title III, Chapter III, provides a regulatory }\end{array}$ \\
\hline
\end{tabular}




\begin{tabular}{|c|c|}
\hline & $\begin{array}{l}\text { framework for external auditors. } \\
\text { The onsite supervision is conducted at least annually and quarterly for larger banks where these } \\
\text { systems are validated and reviewed for appropriate coverage. Internally the CNBV has set up a } \\
\text { qualitative directive to review best practices regarding on site supervision and incorporated these } \\
\text { practices in the Supervision Manual, which is continuously updated on the internet for the examiners } \\
\text { in the field. The restructuring within the CNBV also defined specific specialties necessary for } \\
\text { adequate oversight. These specialty areas were created to coordinate with the onsite examiners and } \\
\text { plan the scope of risk focused examinations, in order to issue a consolidated report of examination. } \\
\text { The methodology for conducting each examination is therefore standardized. Preplanning of } \\
\text { examinations ensures newly identified risks are appropriately reviewed by competent staff. } \\
\text { The Circular Unica de Bancos mandates that external auditors report to the CNBV the scope of their } \\
\text { audits, any adjustments to their accounting, and the management letter given to the bank at the end } \\
\text { of the audit. The CNBV has the authority to request work papers and review the audit. In the event } \\
\text { of an inadequate audit, the CNBV will issue a report with their concerns directly to the external audit } \\
\text { firm's management. The CNBV also has the authority to impose fines or request removal of a } \\
\text { partner for failure to follow legislation or regulation. }\end{array}$ \\
\hline Assessment & Compliant. \\
\hline Comments & \\
\hline Principle 17. & $\begin{array}{l}\text { Bank management contact } \\
\text { Banking supervisors must have regular contact with bank management and a thorough } \\
\text { understanding of the institution's operations. }\end{array}$ \\
\hline Description & $\begin{array}{l}\text { A key finding of the } 2001 \text { FSAP was that, notwithstanding the existing legal requirements, on site } \\
\text { supervisors were not assessing in great detail the quality of banks' management and the role of the } \\
\text { board. } \\
\text { The } 2001 \text { FSAP team also noted that the adoption of the circular } 1423 \text { on Risk Management (and, at } \\
\text { that time, the envisaged Internal Control Circular) along with the improvement in the quality of } \\
\text { banks' loan portfolios should make it easier for supervisors to devote more attention to evaluating } \\
\text { the quality of risk management and assessing banks' strategies. } \\
\text { Since } 2001 \text {, there has been an increase in the time and resources allocated to the assessment of the } \\
\text { quality of bank management. At present, banks are required to issue monthly financial reports which } \\
\text { are reviewed by the CNBV. Prior to issuing this report banks must meet with the CNBV officials } \\
\text { who have validated the information. The CNBV meets at a minimum once quarterly with top-tier } \\
\text { banks' management to discuss any concerns and this is documented in the examiner's work papers } \\
\text { especially in cases where deficiencies may require official sanctions. Minutes are taken of exit } \\
\text { meetings after an examination to ensure both parties understand the findings. The CNBV is } \\
\text { sometimes in daily contact with the larger institutions when there are significant changes in the } \\
\text { monthly or quarterly financial reports. }\end{array}$ \\
\hline Assessment & Compliant. \\
\hline Comments & \\
\hline Principle 18. & $\begin{array}{l}\text { Offsite supervision } \\
\text { Banking supervisors must have a means of collecting, reviewing and analyzing prudential reports } \\
\text { and statistical returns from banks on a solo and consolidated basis. }\end{array}$ \\
\hline Description & $\begin{array}{l}\text { The } 2001 \text { FSAP found that the CNBV and the BOM had in place an adequate system to exercise } \\
\text { offsite supervision on a solo basis. However, offsite supervision was not totally efficient when it } \\
\text { came to embracing the activities within groups. The } 2001 \text { FSAP team recommended that greater } \\
\text { coordination with securities supervisors and other supervisory agencies should be implemented. } \\
\text { At present, the offsite supervision is conducted by the CNBV and the BOM through quarterly } \\
\text { reports where financial information from the banks is ultimately reported. These financial reports are }\end{array}$ \\
\hline
\end{tabular}




\begin{tabular}{|c|c|}
\hline & $\begin{array}{l}\text { later validated by on site inspections. The system utilized by both of these supervisors allows offsite } \\
\text { supervision on a solo basis by each entity. However, large financial groups whose consolidated } \\
\text { financial reports encompass numerous activities require close coordination with other supervisors to } \\
\text { ensure all activities are transparent. The CNBV has the authority to fine and sanction banks for poor } \\
\text { information and even bank officials individually. }\end{array}$ \\
\hline Assessment & Compliant. \\
\hline Comments & \\
\hline Principle 19. & $\begin{array}{l}\text { Validation of supervisory information } \\
\text { Banking supervisors must have a means of independent validation of supervisory information } \\
\text { either through onsite examinations or use of external auditors. }\end{array}$ \\
\hline Description & $\begin{array}{l}\text { The } 2001 \text { FSAP team noted that the CNBV was contemplating the adoption of a regulation of } \\
\text { external auditors that should contribute to enhancing their contribution to the supervisory process. } \\
\text { At present, validation of supervisory information is conducted by the CNBV's examination teams } \\
\text { consisting of four to six examiners during a two- to three-month period in accordance with the risks } \\
\text { and size of the bank. } \\
\text { The CNBV has enacted provisions regarding external auditors. These regulations are included in the } \\
\text { Circular Unica de Bancos which, as noted above, compiles in one provision all banking regulations } \\
\text { issued by the CNBV. The CNBV is also actively involved in the creation of an oversight framework } \\
\text { for external auditors in Mexico. }\end{array}$ \\
\hline Assessment & Compliant. \\
\hline Comments & \\
\hline Principle 20. & $\begin{array}{l}\text { Consolidated supervision } \\
\text { An essential element of banking supervision is the ability of the supervisors to supervise the } \\
\text { banking group on a consolidated basis. }\end{array}$ \\
\hline Description & $\begin{array}{l}\text { The } 2001 \text { FSAP noted that the SHCP had the licensing authority for both banking institutions and its } \\
\text { subsidiaries and financial groups. The CNBV, through its supervision of those entities, had the full } \\
\text { understanding of all those banking groups. Also, the CNBV, through its supervision of a banking } \\
\text { institution and its subsidiaries, could assess the risk exposures of activities or investments in } \\
\text { nonbanking entities and their threat to the bank. } \\
\text { The } 2001 \text { FSAP team also noted that the LIC permitted the CNBV to conduct onsite examinations } \\
\text { on the overall activities of a bank and its banking subsidiaries either directly or indirectly. Annual } \\
\text { examinations of a bank included an examination of any overseas office that could materially affect } \\
\text { the operations of the bank owing to its size. This included supervision of financial subsidiaries and } \\
\text { nonfinancial subsidiaries that performed outsourcing functions for the bank. However, nonfinancial } \\
\text { subsidiaries that were not performing outsourcing functions for the bank were not under the } \\
\text { supervision of the CNBV and, therefore, could not be under the banking group. Information on } \\
\text { subsidiaries was made available by other supervisors or by the banking entity. } \\
\text { The } 2001 \text { FSAP team also found that all banks had to provide consolidated information to the } \\
\text { CNBV. However, in practice, the CNBV reviewed all financial information provided by financial } \\
\text { conglomerates, but did not mandate to provide information on capital adequacy, lending limits, and } \\
\text { large credit exposures. Banking groups did not provide consolidated financial information to the } \\
\text { CNBV. } \\
\text { The } 2001 \text { FSAP team also noted that the CNBV did not supervise insurance and pension entities, but } \\
\text { could request information from the functional regulators. However, the CNBV did not request this } \\
\text { information in practice. The securities branch of the CNBV did not communicate onsite and offsite } \\
\text { examination results with its banking counterparts unless there was a specific need. } \\
\text { At present, capital adequacy requirements continue to be set only at the level of individual entities, }\end{array}$ \\
\hline
\end{tabular}




\begin{tabular}{|c|c|}
\hline & $\begin{array}{l}\text { and not at a consolidated group level, which creates opportunities for multiple gearing. Also, } \\
\text { simultaneous inspections fall short of truly joint inspections and the figure of lead supervisor does } \\
\text { not exist; as a result, there is a need to develop an adequate regulatory and supervisory view on the } \\
\text { financial group as a whole. It should be noted that conglomerate risks are mitigated by the civil code } \\
\text { based Mexican legal framework which sets out with great precision the permissible activities for } \\
\text { each type of financial entity. This creates segmentations that, while hindering synergies and } \\
\text { financial innovation, limit conglomerate risks. As groups increasingly follow a group-wide strategy, } \\
\text { the scope for such risks inevitably widens. As regards interagency coordination, it could be further } \\
\text { boosted via strong MOUs between agencies, setting out leadership roles, responsibilities, and } \\
\text { accountabilities for information gathering, regulation, and inspection. Moreover, the } \\
\text { regulatory/supervisory architecture continues to be complex and based on a silo structure, leaving } \\
\text { room for further simplification, better allocation of responsibilities and powers, and increased } \\
\text { coordination. In addition, the leadership role of SHCP in financial development policy, which has } \\
\text { been carried out successfully but de facto, could be formalized and enhanced, especially if and when } \\
\text { many of the regulatory functions now with SHCP are transferred to the Commissions. Finally, the } \\
\text { full political and budgetary autonomy (subject to adequate accountability) of the various } \\
\text { Commissions is seen as a desirable and healthy objective. Consideration should also be given to } \\
\text { possible alternative options of consolidation of the Commissions in the longer term. }\end{array}$ \\
\hline Assessment & Largely compliant. \\
\hline & $\begin{array}{l}\text { Since the } 2001 \text { FSAP, the trends toward conglomeration (i.e., a variety of financial services provided } \\
\text { by entities of a financial group) and globalization intensified. Conglomeration and } \\
\text { internationalization have profoundly reshaped the Mexican financial market. A substantial portion of } \\
\text { financial sector assets are now being managed by financial groups, mostly foreign owned. Financial } \\
\text { groups are increasingly being managed as groups and by product and business lines, instead of by } \\
\text { separate legal entities. In addition, the phenomenon of parallel banks (independent institutions } \\
\text { licensed in different jurisdictions and linked by common ownership) seems to also be part of this } \\
\text { changing financial landscape, raising further challenges for home/host country supervisor } \\
\text { relationships. } \\
\text { At present, legislation is currently under study by the SHCP with the opinion of the CNBV to ensure } \\
\text { full comprehensive consolidated supervision. However, although current legislation allows adequate } \\
\text { supervision, there continues to be a distribution of duties between several regulators. Bank licensing } \\
\text { and supervision are under different regulators, whereas both functions are under one regulator for } \\
\text { the securities industry and should also be considered for the banking industry. }\end{array}$ \\
\hline & $\begin{array}{l}\text { Accounting standard } \\
\text { Banking supervisors must be satisfied that each bank maintains adequate records drawn up in } \\
\text { accordance with consistent accounting policies and practices that enable the supervisor to obtain a } \\
\text { true and fair view of the financial condition of the bank and the profitability of its business, and } \\
\text { that the bank publishes on a regular basis financial statements that fairly reflect its condition. }\end{array}$ \\
\hline Description & $\begin{array}{l}\text { At the time of the } 2001 \text { FSAP, the CNBV has had its ability to allow forbearance (special register) } \\
\text { on banks substantially limited by the issuance of Circular 1448. The } 2001 \text { FSAP team recommended } \\
\text { the CNBV to strengthen the enforcement of the existing regulations on assets valuation. Also, at that } \\
\text { time, banks' corporate governance had been considerably strengthened by a legislative amendment. } \\
\text { Since 2001, the CNBV has updated the regulatory accounting standard in accordance with } \\
\text { international accounting standards: for instance, to prepare consolidated financial statements banks } \\
\text { have to include subsidiaries whether they are financial entities or not. } \\
\text { The CNBV had already issued regulation related to external auditors in } 1994 \text { and } 2000 \text { (Circulars } \\
1222 \text { and 1479). Modifications were issued in April } 2005 \text { as a result of changes in international } \\
\text { regulation (such as Sarbanes-Oxley). In particular, the definition of "independence" was updated and } \\
\text { revised. Specific guidelines regarding requirements for independence are set for external auditors } \\
\text { and their offices (for instance, audit partner rotation shall not be longer than five years). Providing } \\
\text { additional services other than auditing are limited from the same firm such as bookkeeping or other }\end{array}$ \\
\hline
\end{tabular}




\begin{tabular}{|l|l|}
\hline & $\begin{array}{l}\text { services related to accounting records, design, and implementation of financial information systems, } \\
\text { appraisal or valuation services, internal audit services, and some legal services. }\end{array}$ \\
\hline Assessment & Compliant. \\
\hline Comments & \\
\hline Principle 22. & Remedial measures
\end{tabular}

Banking supervisors must have at their disposal adequate supervisory measures to bring about timely corrective action when banks fail to meet prudential requirements (such as minimum capital adequacy ratios), when there are regulatory violations, or where depositors are threatened in any other way. In extreme circumstances, this should include the ability to revoke the banking license or recommend its revocation.

\begin{tabular}{|l|l}
\hline Description & The 2001 FSAP team noted that, owing to the turmoil caused by a banking crisis of systemic scale,
\end{tabular} the CNBV's role had consisted, to a large extent, of helping to minimize the disruptive effects of bank distress, which resulted in prudential forbearance. The CNBV had been rather reluctant to use penalties as a means of achieving better market discipline mainly because of two reasons. First, the CNBV confronted difficulties in enforcing sanctions - long delays, questionable legal base for taking action, inefficient judicial system. Second, the CNBV had been reluctant to resort to harsh sanctions at a time when banks were striving to recover from the effects of the crisis.

The 2001 FSAP team also noted that the creation of IPAB in 1999 was achieved without ensuring consistency with the existing legal provisions pertaining to intervention. Hence, the existing legal framework had not been facilitating an effective cooperation between IPAB and the CNBV-also partly due to legal uncertainties - , nor had it been conducive to the winding down of banks' operations, where needed.

At the time of the 2001 FSAP, a Prompt Corrective Action system (PCA) with the aim of making it easier for supervisors to intervene banks had been recently adopted. This system was expected to mitigate the risk of excessive discretion on the part of supervisors and also, to some extent, to immunize supervisors from political interference.

Under that system, banks were going to fall into four categories, which reflected the importance of their capital. Predetermined actions were going to be taken by supervisors depending on the classification of the bank into these categories. Once the lowest level of capital was reached, the supervisor would have no option but to intervene the bank, which in all likelihood would consist of liquidating it. This mechanism, while presumably very effective, was going to be adopted only if certain conditions were in place. For example, in view of the CNBV's track record with respect to forbearance, it was of the utmost importance going forward for the CNBV's credibility that predetermined actions were enforced.

However, the 2001 FSAP team noted that there was a discussion at that time as to whether a bank being in the lowest category should automatically be intervened. This hesitation seemed to point to the authorities' reluctance to give in to the possibility of taking discretionary actions.

The 2001 FSAP team indicated that the existing legal framework/process for dealing with problem banks was rather complex, as two institutions (the CNBV and IPAB) were involved in dealing with problem banks, without sufficient clear delineation of their respective responsibilities.

The 2001 FSAP team noted that the CNBV had the power to intervene banks in two ways. First, the CNBV could decide to have the bank's activities closely monitored, in view of certain shortcomings that, however important, did not pose a threat to the bank's existence. Under such circumstances, the CNBV could instruct one of its staff to reside in the bank to ensure that the remedial actions imposed by the CNBV were effectively implemented. According to this mechanism, called "administrative intervention," the administrator, while having unfettered access to all information, would not be entrusted with any power other than reporting to the CNBV on the bank's progress in correcting deficiencies. The second mechanism, "managerial intervention," consisted for the CNBV to intervene a bank that was presumably insolvent. The administrator designed by the CNBV was empowered to take any decision with respect to the bank's day-to-day operations and its resolution 
(shareholders and management were deprived of most of their powers since capital had become negative). Actions were to be taken in the best interest of the depositors under the CNBV's control. The law did not instruct the CNBV to request IPAB's support (technical or financial), nor did it require that, after a certain period, IPAB be assigned to the resolution of the bank.

At the same time, IPAB was the institution which, in addition to its role as deposit insurer, had the responsibility to liquidate banks. The "trigger" point for IPAB to be involved either in the rehabilitation of the bank or its resolution was when it was called for providing financial support. For example, a bank facing a liquidity shortage would be eligible to use IPAB's facilities (limited to a six-month facility that could be renewed only once for the same period). Under this scenario, IPAB's support was subordinated to an evaluation of the bank's solvency and prospects by a third party, which was to be submitted to, and approved by the CNBV. If IPAB was unsuccessful in rescuing the ailing bank, its involvement in the resolution process would be stepped up. IPAB could also be entrusted with the liquidation of the bank at the CNBV's request, for example if the deposit insurance mechanism was to be relied upon for reimbursing depositors.

In view of the existing legal arrangements at the time of the 2001 FSAP, both the CNBV and IPAB were involved in the resolution process creating some confusion. The 2001 FSAP team indicated that a clarification of their respective roles could consist of empowering IPAB with the lead role for intervention, except for the "administrative intervention" that should normally take place before the lowest point of the PCA was reached.

The 2001 FSAP team was of the view that amending the supervisory process with a view to eliminating forbearance and political interference without, at the same time, overhauling the resolution process, was unlikely to bring about major improvements. Short of reforming the overall process, forbearance would still be possible, as the CNBV would still be empowered to intervene banks without limitation in time, as was the case at the time of the 2001 FSAP. Allowing the CNBV to intervene banks during a limited period — as a means of clarifying the resolution process - after which the resolution responsibility would be transferred to IPAB was not going to be satisfactory either, as it was seen to perpetuate the existing system.

The 2001 FSAP team noted that, looking forward, it would be highly preferable to have the PCA adopted at the same time the legal framework on resolution/intervention was streamlined. The CNBV should have full responsibility for the supervision of banks up to the point where the bank was to be intervened (PCA). Afterwards, IPAB would be fully responsible for, and in charge of the subsequent actions to be taken, leading either to rehabilitation or liquidation. Since the intervened bank would keep its bank legal status until its license was withdrawn, the CNBV would continue to be responsible for its supervision.

Since the 2001 FSAP mission, several changes were introduced in this area. A new article (134 Bis) in the LIC established the basis of the CNBV's system of PCA in line with best international practices. In November 2004, the CNBV issued the "Reglas de Carácter General a que se refiere el Articulo 134 Bis de la Ley de Instituciones de Crédito." These rules provide the general framework for the PCA.

The new Circular Única de Bancos (Title V, Chapter I) establishes an early warning system. In addition, the CNBV provides information over its website by rating the banks' capital levels in five categories. These capital levels are in accordance with the standards set by the BOM and the regulations set forth by the SHCP. The system was tested in 2004 when a bank's capital fell below the authorized capital level due to derivatives trading.

An additional and major step forward was achieved through the introduction in April 2006 of a new legal framework for bank resolution. The former bank resolution framework was heavily biased in favor of open-bank resolution, under which IPAB had strong powers to take full control of an insolvent bank, write off or substantially dilute the shareholders' equity, recapitalize and rehabilitate it, and sell it back to the private sector, keeping it open to the public all along. Open-bank resolution, however, became incompatible with the now limited deposit guarantee. Moreover, the former legal framework was inadequate to the task of efficiently and swiftly closing, resolving, and liquidating nonviable banks. The new law has very positive features. It includes cessation of payments as a 


\begin{tabular}{|c|c|}
\hline & $\begin{array}{l}\text { trigger for bank resolution. It provides for information exchange between relevant agencies. It } \\
\text { establishes flexible options for closed-bank resolution-insured deposit transfers, purchase and } \\
\text { assumptions (P\&A), and bridge banks-subject to a less cost criteria. It improves legal protection } \\
\text { for supervisors acting. And it leaves the possibility for open-bank resolution in the case of banks } \\
\text { considered to be "too-big-to-close" by a "Financial Stability Committee" composed of the highest } \\
\text { relevant authorities. }\end{array}$ \\
\hline Assessment & Largely compliant. \\
\hline Comments & $\begin{array}{l}\text { Significant progress was made in prompt corrective actions and new legislation on bank resolution } \\
\text { was very recently introduced, but some challenges remain. The prompt corrective regime is } \\
\text { consonant with international best practices. The recent approval of a new legal framework for bank } \\
\text { resolution is a significant step forward, but aspects concerning the resolution of "too-big-to-close" } \\
\text { banks need close attention. In particular, banks' statutes should be amended as soon a possible to } \\
\text { enable the so-called "conditioned capital restoration plan" and suitable internal regulations and } \\
\text { guidelines need to be developed with regard to the determination of the size of the haircut to be } \\
\text { applied to uninsured creditors. A legal reform of the bank liquidation framework is pending. IPAB } \\
\text { has substantially contributed to reestablishing financial system soundness, but it is still saddled with } \\
\text { having to manage the debt related to the depositor bailout effected during the } 1995 \text { crisis. The } \\
\text { servicing of this debt is preventing IPAB from being able to accumulate the deposit insurance fund, } \\
\text { which weakens IPAB credibility. The authorities are encouraged to seek a suitable formula to } \\
\text { alleviate the financial condition of IPAB, including the transferring of IPAB's debt to the Federal } \\
\text { Government (which would require legal reform). The deposit insurance framework needs to be } \\
\text { better aligned with international best practices regarding coverage, base, and risk-based premiums. } \\
\text { There is also a need to formalize internal procedures in the BOM for contingency planning and the } \\
\text { lender-of-the-last-resort function. There is also the need to establish a framework and operational } \\
\text { guidelines for the resolution of financial groups, taking into account the fact that the systemically } \\
\text { important groups are foreign owned. }\end{array}$ \\
\hline \multirow[t]{2}{*}{ Principle 23.} & Globally consolidated supervision \\
\hline & $\begin{array}{l}\text { Banking supervisors must practice global consolidated supervision over their internationally active } \\
\text { banking organizations, adequately monitoring and applying appropriate prudential norms to all } \\
\text { aspects of the business conducted by these banking organizations worldwide, primarily at their } \\
\text { foreign branches, joint ventures and subsidiaries. }\end{array}$ \\
\hline \multirow[t]{3}{*}{ Description } & $\begin{array}{l}\text { The } 2001 \text { FSAP team recommended the CNBV to continue supervising subsidiaries and branches } \\
\text { operating abroad, in view of the risks generally entailed with activities performed away from } \\
\text { headquarters. Special attention should be given to preserving the quality of this supervision, } \\
\text { notwithstanding the budget restrictions faced by the CNBV at that time. }\end{array}$ \\
\hline & $\begin{array}{l}\text { The CNBV has the authority to supervise the overseas activities of institutions chartered in Mexico } \\
\text { (LIC, Article 89). Banking institutions submit annually to the SHCP their projects on the } \\
\text { establishment, and relocation of their overseas activities. The CNBV receives detailed information } \\
\text { on the activities of foreign subsidiaries/branches and rely on onsite inspections to determine whether } \\
\text { headquarter management has adequate systems for monitoring these activities. The CNBV also } \\
\text { conducts onsite inspections in foreign subsidiaries/branches of Mexican banks, in cases it is } \\
\text { considered that these activities may pose a risk for the bank at large. Onsite examiners verify } \\
\text { whether banks have adequate oversight of their foreign activities and they also ensure that head } \\
\text { office monitors compliance with internal controls and the risks taken by their overseas entities. The } \\
\text { CNBV ascertains that the oversight of the host supervisor takes into consideration the scope and } \\
\text { assistance it can obtain, when undertaking controls oversees. }\end{array}$ \\
\hline & $\begin{array}{l}\text { The CNBV continues to supervise Mexican subsidiaries, agencies, and branches abroad with its } \\
\text { ongoing review of each bank's strategic plan under the Circular Unica de Bancos noted above. } \\
\text { Difficulty is noted in the structures set up by Mexican individuals that basically form parallel banks } \\
\text { in other jurisdictions. Although the shareholders are the same, the bank is set up in a foreign } \\
\text { jurisdiction where the CNBV has no authority. When the foreign bank is owned by a holding } \\
\text { company the CNBV has authority to request financial information to satisfy its concerns. Currently }\end{array}$ \\
\hline
\end{tabular}




\begin{tabular}{|c|c|}
\hline & $\begin{array}{l}\text { Mexican banks are performing data processing functions for foreign subsidiaries and the CNBV has } \\
\text { authority to review the process. However, outsourcing to entities outside of Mexico may cause } \\
\text { problems for the CNBV in the future. }\end{array}$ \\
\hline Assessment & Largely compliant. \\
\hline Comments & \\
\hline Principle 24. & $\begin{array}{l}\text { Host country supervision } \\
\text { A key component of consolidated supervision is establishing contact and information exchange } \\
\text { with the various other supervisors involved, primarily host country supervisory authorities. }\end{array}$ \\
\hline Description & $\begin{array}{l}\text { The CNBV is permitted by Article } 117 \text { of the LIC to sign MOUs with home country supervisors } \\
\text { where the parent organization of the Mexican bank resides. These MOUs consist of information } \\
\text { sharing agreements which include, inter alia, advising the home country supervisor of any adverse } \\
\text { development with respect to a bank's operations, whether it relates to the quality of risk } \\
\text { management, internal controls, or to any other material factor that occur at the Mexican bank. Under } \\
\text { the MOUs home country supervisors provide information as to the structure and overall framework } \\
\text { of supervision under which their bank (the head office) operates, as well as any significant problems } \\
\text { which may arise at the head office or at related companies. In addition, Mexican onsite examination } \\
\text { teams travel to jurisdictions where Mexican banks have branches, agencies, or subsidiaries and, in } \\
\text { conjunction with host country supervisors, conduct joint examinations. } \\
\text { Article } 45 \text { of the LIC allows a home country supervisor to visit Mexico and conduct examination in } \\
\text { conjunction with the Mexican supervisory onsite team. The CNBV can advise the SHCP to restrict } \\
\text { the expansion of Mexican banks to jurisdictions where legal provisions on secrecy may hinder the } \\
\text { CNBV's supervision. } \\
\text { The CNBV continues dialog with home country supervisors of all foreign banks represented in } \\
\text { Mexico. Primarily the supervisors of the U.S., Canada, and Spain regularly meet with the CNBV and } \\
\text { discuss mutual concerns. Joint examinations with foreign supervisory entities are permitted with } \\
\text { advance notice and provided an MOU is in place prior to the examination. }\end{array}$ \\
\hline Assessment & Compliant. \\
\hline Comments & \\
\hline Principle 25. & $\begin{array}{l}\text { Supervision over foreign banks' establishments } \\
\text { Banking supervisors must require the local operations of foreign banks to be conducted to the } \\
\text { same high standards as are required of domestic institutions and must have powers to share } \\
\text { information needed by the home country supervisors of those banks for the purpose of carrying out } \\
\text { consolidated supervision. }\end{array}$ \\
\hline Description & $\begin{array}{l}\text { The } 2001 \text { FSAP team noted that the CNBV had agreed upon a MOU with Spain and was about to } \\
\text { sign a MOU with the U.S. Federal Reserve System and the Office of the Comptroller of the } \\
\text { Currency, to ensure proper supervision of cross-border activities. However, there was a limitation at } \\
\text { the time for disclosing information (bank secrecy) which prevented foreign supervisors from gaining } \\
\text { access to information deemed as necessary to form examination conclusions. Legislative } \\
\text { amendments were about to be proposed at that time to lift this limitation and allow the CNBV to } \\
\text { share information with foreign financial supervisors on a broad basis. } \\
\text { These days, Article } 45 \text {-D of the LIC establishes the general principle that foreign banks are to be } \\
\text { dealt with the same treatment as domestic banks. Article } 45-\mathrm{N} \text { of the LIC confers to the CNBV the } \\
\text { responsibility for the supervision of these entities under the same regulatory framework as applied to } \\
\text { domestic banks. This same Article establishes that foreign supervisors are entitled to conduct } \\
\text { examinations jointly with the CNBV staff on banks in which a foreign bank has the majority of } \\
\text { capital share. Article } 4 \text { of the CNBV's Law enables the CNBV to share relevant information with the } \\
\text { home country supervisors of the subsidiaries established in Mexico. } \\
\text { Since } 2001 \text {, the CNBV has signed bilateral MOUs with } 12 \text { foreign bank regulatory agencies and is }\end{array}$ \\
\hline
\end{tabular}




\begin{tabular}{|l|l|}
\hline & $\begin{array}{l}\text { currently negotiating eight more with the authorities of several Western Hemisphere and European } \\
\text { countries. The noted 12 MOUs are primarily with supervisors of the major banking institutions with } \\
\text { subsidiaries in Mexico. The CNBV has also signed 34 MOUs with securities regulatory agencies } \\
\text { abroad. }\end{array}$ \\
\hline Assessment & Compliant. \\
\hline Comments & \\
\hline
\end{tabular}

Table 2. Summary of Compliance with Basel Core Principles

\begin{tabular}{|l|c|c|c|c|c|}
\hline \multicolumn{1}{|c|}{ Core Principle } & $\mathrm{C}^{\underline{1}}$ & $\mathrm{LC}^{-}$ & $\mathrm{MNC}^{3 /}$ & $\mathrm{NC}^{4 /}$ & $\mathrm{NA}^{\frac{5}{}}$ \\
\hline 1. Objectives, Autonomy, Powers, and Resources & & & & $\mathbf{X}$ & \\
\hline 1.1 Objectives & & & & $\mathbf{X}$ & \\
\hline 1.2 Independence & & $\mathbf{X}$ & & & \\
\hline 1.3 Legal framework & $\mathbf{X}$ & & & & \\
\hline 1.4 Enforcement powers & $\mathbf{X}$ & & & & \\
\hline 1.5 Legal protection & & & & & \\
\hline 1.6 Information sharing & $\mathbf{X}$ & & & & \\
\hline 2. Permissible Activities & $\mathbf{X}$ & & & & \\
\hline 3. Licensing Criteria & $\mathbf{X}$ & & & & \\
\hline 4. Ownership & & $\mathbf{X}$ & & & \\
\hline 5. Investment Criteria & $\mathbf{X}$ & & & & \\
\hline 6. Capital Adequacy & $\mathbf{X}$ & & & & \\
\hline 7. Credit Policies & $\mathbf{X}$ & & & & \\
\hline 8. Loan Evaluation and Loan-Loss Provisioning & $\mathbf{X}$ & & & & \\
\hline 9. Large Exposure Limits & & $\mathbf{X}$ & & & \\
\hline 10. Connected Lending & $\mathbf{X}$ & & & & \\
\hline 11. Country Risk & $\mathbf{X}$ & & & & \\
\hline 12. Market Risks & $\mathbf{X}$ & & & & \\
\hline 13. Other Risks & $\mathbf{X}$ & & & & \\
\hline 14. Internal Control and Audit & $\mathbf{X}$ & & & & \\
\hline 15. Money Laundering & $\mathbf{X}$ & & & & \\
\hline 16. Onsite and Offsite Supervision & $\mathbf{X}$ & & & & \\
\hline 17. Bank Management Contact & $\mathbf{X}$ & & & & \\
\hline 18. Off-Site Supervision & $\mathbf{X}$ & & & & \\
\hline 19. Validation of Supervisory Information & $\mathbf{X}$ & & & & \\
\hline 20. Consolidated Supervision & & $\mathbf{X}$ & & & \\
\hline 21. Accounting Standards & $\mathbf{X}$ & & & & \\
\hline 22. Remedial Measures & $\mathbf{X}$ & & & & \\
\hline 23. Globally Consolidated Supervision & & & & \\
\hline 24. Host Country Supervision & & & & \\
\hline $\begin{array}{l}\text { 25. Supervision Over Foreign Banks' } \\
\text { Establishments }\end{array}$ & & & & & \\
\hline
\end{tabular}




\section{Table 3. Recommended Action Plan to Improve Compliance of the Basel Core Principles}

\begin{tabular}{|c|c|}
\hline Reference Principle & Recommended Action \\
\hline Principle 1 & $\begin{array}{l}\text { In stages make the CNBV a single autonomous supervisory agency with power to } \\
\text { control its own budget that will ensure a continuous improvement of its systems, } \\
\text { examination procedures, highly skilled personnel, and supervision of its constituents. } \\
\text { During this transition, to minimize political interference from other regulatory agencies } \\
\text { and reduce having to seek approval through opinions from the other regulators, it } \\
\text { would be prudent to have regular meetings with the other supervisors to set priorities } \\
\text { on the delivery of opinions in the processing of bank applications or interpretation and } \\
\text { clarification of laws and regulations. In the final stage the CNBV would have full } \\
\text { power to license or revoke licenses of any bank, nonbank intermediary, or financial } \\
\text { group and demand full disclosure on a consolidated basis with the concurrence of the } \\
\text { CNBV's Board of Directors. }\end{array}$ \\
\hline Principle 5 & $\begin{array}{l}\text { The CNBV should continue working to prepare amendments to the LIC which would } \\
\text { permit the CNBV to have formal authority in the process of approving investments by } \\
\text { the banking institutions. In practice, the CNBV has a definitive voice by delivering } \\
\text { their opinion to the SHCP on each individual applicant and the SHCP has historically } \\
\text { followed the opinion of the CNBV in these matters. }\end{array}$ \\
\hline Principle 10 & $\begin{array}{l}\text { Although the CNBV has improved its control over related party lending by comparing } \\
\text { the monthly data received from the banks to a peer group and requiring the Board of } \\
\text { Directors' approval for related loans which are limited to } 50 \text { percent of the bank's } \\
\text { capital, parallel banking institutions continue to pose a threat that is not readily } \\
\text { discovered when preferential treatment on loans is granted by the bank to these } \\
\text { institutions. To avoid capital deficiencies, it is worth considering limiting credit to } \\
\text { shareholders not on Tier } 1 \text { capital, but rather on the shareholder's investment. In doing } \\
\text { so, a shareholder could not be granted loans that exceed the value of its investment in } \\
\text { the bank. }\end{array}$ \\
\hline Principle 20 & $\begin{array}{l}\text { The CNBV should have full power to license or revoke licenses of any bank, nonbank } \\
\text { subsidiary, or financial group and demand full disclosure on a consolidated basis with } \\
\text { the concurrence of the CNBV's Board of Directors. Legislation must give the CNBV } \\
\text { the authorization to approve investments or outsourcing of critical functions by all } \\
\text { banks or financial groups, and the ability to examine these institutions on an enterprise- } \\
\text { wide basis. }\end{array}$ \\
\hline Principle 22 & $\begin{array}{l}\text { Improvements are needed in the area of bank resolution when prompt corrective action } \\
\text { has been undertaken by ensuring that the CNBV has full power to determine when a } \\
\text { bank's license must be revoked. Delaying actions taken by the shareholders in court } \\
\text { should not be allowed to hamper the efforts of the CNBV in revoking licenses. Bank } \\
\text { resolution legislation was approved by Congress in April } 2006 \text {. }\end{array}$ \\
\hline Principle 23 & $\begin{array}{l}\text { Continue to formulate legislation for passage by congress to allow the CNBV to } \\
\text { supervise financial or nonfinancial institutions set up by Mexican individuals that form } \\
\text { parallel banks in jurisdictions where the CNBV has no authority. When the foreign } \\
\text { bank is owned by a holding company, the CNBV has the authority to request financial } \\
\text { information to satisfy its concerns. However, Mexican banks are performing data- } \\
\text { processing functions for foreign subsidiaries, as well as outsourcing to entities outside } \\
\text { of Mexico. The CNBV should have the supervisory authority to review these functions } \\
\text { regardless of jurisdiction. Further improvements in legislation must be made to give } \\
\text { the CNBV the authorization to approve investments or outsourcing of all banks or } \\
\text { financial groups and the ability to examine these institutions on an enterprise-wide } \\
\text { basis. }\end{array}$ \\
\hline
\end{tabular}




\section{Authorities' response}

17. The financial authorities have willingly cooperated with the World Bank and the International Monetary Fund during the progress of the 2006 Financial Sector Assessment Program carried out in Mexico. In our opinion the assessment has been carried out in a highly professional manner.

18. In connection with the assessment of compliance with the Basel Core Principles for Effective Banking Supervision, we consider that the report provides a fair appraisal of the implementation by the National Banking and Securities Commission (CNBV) of the principles.

19. We will continue our efforts to strengthen our prudential framework and to incorporate new international best practices as they may arise. However, the broad challenge ahead remains the achievement of an autonomous status for the CNBV. Although the impending reallocation of powers among financial authorities will be a significant step forward, we must maintain our efforts in bringing proposals to the legislative branch that will ensure an independent supervisor in accordance with international best practices. 